INSTITUTO DE PESQUISAS ENERGÉTICAS E NUCLEARES

Autarquia associada à Universidade de São Paulo

ESTUDO DO COMPORTAMENTO MECÂNICO DE CILINDROS DE COMPÓSITO EPÓXI/FIBRA DE BASALTO EM ENSAIOS HIDROSTÁTICOS

MAURO HENRIQUE LAPENA

Dissertação apresentada como parte dos requisitos para a obtenção do Grau de Mestre em Ciências na Área de Tecnologia Nuclear - Materiais.

Orientador:

Prof. Dr. Gerson Marinucci 
À minha esposa, Nathali. Aos meus pais, Regina e Paulo. Ao meu irmão, Murilo. 


\section{AGRADECIMENTOS}

Aos meus pais, Regina e Paulo, por todo apoio, dedicação, por estimularem meus estudos, por sempre me incentivarem aos melhores caminhos. Ao meu irmão Murilo, pelo companheirismo e por viver comigo boas histórias da vida.

À minha amada esposa Nathali, pelo apoio, compreensão, carinho, amor e companheirismo. Cada etapa deste trabalho recebeu de alguma forma sua participação, seu amor foi fundamental em todas elas, não tenho dúvidas de que muito contribuiu para esta nossa nova conquista.

Ao meu orientador, Dr. Gerson Marinucci, por todo apoio prestado, pela paciência, pelo conhecimento e experiência transmitidos. Por sempre acreditar e incentivar a realização deste trabalho, apesar dos osbtáculos que enferntamos.

À CPIC, por oferecer a fibra de vidro, e à Basfiber, por oferecer a fibra de basalto.

Aos colegas do CTMSP, Osni de Carvalho, João Claudino de Godois Netto, Daniel Bina, Rafael Alves de Camargo, Everton Marcelino Soares, Paulo Jorge Abib Junior, Leandro Alves Maldonado, pelo apoio oferecido.

Aos colegas do DCTA, Carlos Alberto Alves Cairo, Dario Sumizo Yamagishi, Fabio Rogerio de Oliveira Morais, João Marcos Kruszynsky de Assis, João Batista Rodrigues, Jefferson Rodrigues Tavares, Maria Aparecida Miranda de Souza, Miriam Kasumi Hwang Yassuda, João Carlos Fernandes, pelo auxílio e profissionalismo.

A Deus, por todas as oportunidades de trabalho e aprendizado.

Minha gratidão a todos que de alguma forma contribuíram para a realização deste trabalho. 


\title{
ESTUDO DO COMPORTAMENTO MECÂNICO DE CILINDROS DE COMPÓSITO EPÓXI/FIBRA DE BASALTO EM ENSAIOS HIDROSTÁTICOS
}

\author{
Mauro Henrique Lapena
}

\begin{abstract}
RESUMO
O objetivo deste trabalho foi estudar o comportamento mecânico de cilindros de compósito polimérico reforçado com fibras. Para isso, foram produzidos cilindros com extremidades abertas reforçados com fibra de basalto e fibra de vidro, utilizando a técnica de enrolamento filamentar (filament winding). Estes cilindros foram submetidos a ensaio hidrostático com carregamento circunferencial, ensaio de ruptura de anel (split disk test) e ensaio de resistência ao cisalhamento interlaminar (ILSS). Uma placa do compósito de fibra de basalto foi produzida por enrolamento filamentar, para caracterização por ensaio de resistência à tração. Todos cilindros submetidos ao ensaio hidrostático apresentaram fratura localizada em uma faixa de altura do cilindro, com extensas delaminações das camadas circunferenciais. Os compósitos epóxi/fibra de basalto superaram ou igualaram os de compósito epóxi/fibra de vidro nas comparações entre resultados dos valores das propriedades mecânicas avaliadas, nas porcentagens: resistência à tração aparente de ruptura de anel em 45\% e 43\% em resistência específica; ILSS, em 11\%; resistência/tensão de membrana de ruptura no ensaio hidrostático, em $55 \%$.
\end{abstract}

Palavras-chave: ensaio hidrostático, fibra de basalto, compósito de matriz polimérica, caracterização mecânica, filament winding. 


\title{
STUDY OF MECHANICAL BEHAVIOR OF EPOXY/BASALT FIBER COMPOSITE CYLINDERS UNDER HYDROSTATIC TESTS
}

\author{
Mauro Henrique Lapena
}

\begin{abstract}
The aim of this work was to study the mechanical behavior of fiber reinforced polymer composite cylinders. For this purpose, cylinders reinforced with basalt and glass fibers were produced, with open-ended geometry, using filament winding technique. These cylinders were submitted to hydrostatic test under circunferential loading, split disk (ring segment) test and interlaminar shear strength (ILSS). A basalt fiber composite plate was produced by filament winding for characterization by tensile strength test. All cylinders submitted to hydrostatic test presented fracture located in the height range of the cylinder, with extensive delamination of the circumferential layers. The epoxy/basalt fiber composites overcame or equated the epoxy/glass fiber composites in comparisons between results of the mechanical properties, tensile strength in split disk, in $45 \%$ and $43 \%$ in specific strength; ILSS in 11\%; membrane tensile strength in the hydrostatic test, in $55 \%$.
\end{abstract}

Keywords: hydrostatic test, basalt fiber, polymer matrix composite, mechanical characterization, filament winding. 


\section{Lista de Figuras}

FIGURA 1 - Cilindro de armazenamento de gás natural reforçado com epóxi/FB e novelo de filamento de FB (www.basfiber.com, 2014).

FIGURA 2 - Corpos-de-prova em formato de anel compósito de fibra de basalto (Pavlovsky et al., 2007) .........................................................................

FIGURA 3 - Máquina de enrolamento filamentar (Strong, 1989)..........................

FIGURA 4 - Compósito laminado e seu código de identificação. ..........................11

FIGURA 5 - Visão geral dos modos de falha em uma lâmina (Laffan et al., 2012).

FIGURA 6 - Fabricação da placa de compósito reforçado com FB......................14

FIGURA 7 - Produção do cilindro reforçado com FB.......................................16

FIGURA 8 - Aquecimento de amostra do compósito epóxi/FB em bico de Bunsen.

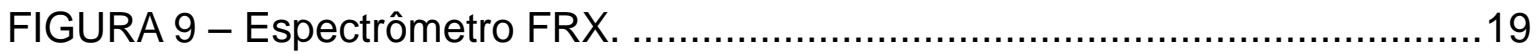

FIGURA 10 - Dispositivo de ensaio de ruptura de anel (Marinucci, 2011) ...........20

FIGURA 11 - Esquema do corte de um corpo de prova para ensaio ILSS

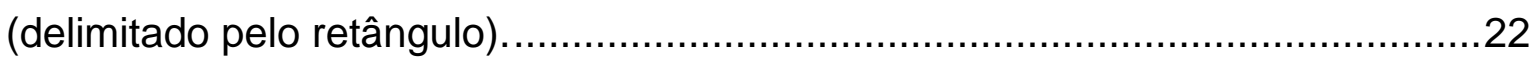

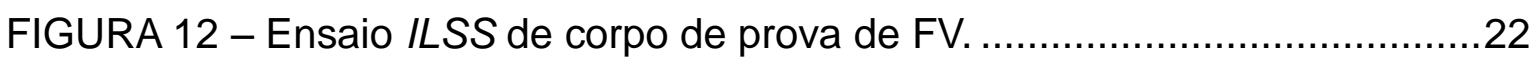

FIGURA 13 - Dispositivo de ensaio hidrostático (Marinucci, 2001: (a) desenho esquemático, (b) exemplar fabricado com fibra de basalto, (c) detalhe do bico de

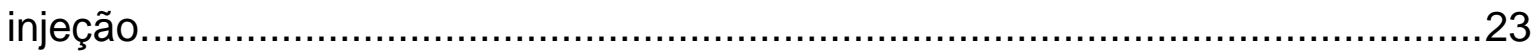

FIGURA 14 - Calorímetro exploratório diferencial. ..........................................25

FIGURA 15 - Curvas de análise DSC dos compósitos de epóxi/FB e epóxi/FV. ..28 FIGURA 16 - Comparação entre a resistência à tração aparente de ruptura do

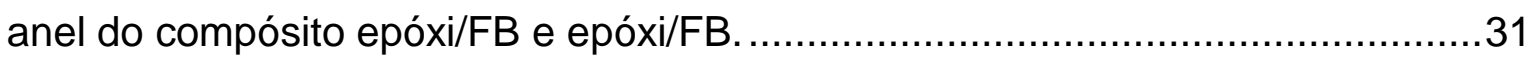

FIGURA 17 - Comparação entre a resistência à tração aparente específica de ruptura do anel do compósito epóxi/FB e epóxi/FB.............................................31

FIGURA 18 - Corpo de prova split disk do compósito epóxi/FB. ..........................32

FIGURA 19 - Corpo de prova split disk do compósito epóxi/FV. ...........................32 FIGURA 20 - Comparação entre o aspecto dos corpos-de-prova de compósito de epóxi/FB e epóxi/FV após ensaio de viga curta. 
FIGURA 21 - Aspecto dos cilindros de compósito epóxi/FB após ensaio hidrostático.

FIGURA 22 - Região de fratura do cilindro de compósito epóxi/FB após ensaio hidrostático mostrando (a) lado externo e (b) lado interno.

FIGURA 23 - Aspecto dos cilindros de compósito epóxi/FV após ensaio hidrostático.

FIGURA 24 - Região de fratura do cilindro de compósito epóxi/FV após ensaio hidrostático mostrando (a) lado externo e (b) lado interno. 38 FIGURA 25 - Ilustração esquemática da fratura do cilindro durante ensaio hidrostático na (a) região de fatura, com representação em (b) corte através da região da região de fratura, mostrando a (c) fratura da camada helicoidal e da (d) da camada circunferencial. 40

FIGURA 26 - Micrografia da seção longitudinal do cilindro de compósito epóxi/FB.

FIGURA 27 - Micrografia da seção longitudinal do cilindro de compósito epóxi/FV.

FIGURA 28 - MEV das FB sem impregnação de resina epóxi. 43 FIGURA 29 - MEV da fratura translaminar da camada circunferencial do compósito epóxi/FB. 43

FIGURA 30 - MEV da camada circunferencial do compósito epóxi/FB. 44 FIGURA 31 - MEV em detalhe da camada circunferencial do compósito epóxi/FB (demarcado pelo retângulo na FIG. 30). 


\section{Lista de Tabelas}

TABELA 1 - Porcentagem em massa (intervalo) dos óxidos constituintes da FB e da FV tipo $\mathrm{E}$

TABELA 2 - Comparação entre as propriedades das fibras (Colombo et al., 2012. In: Burgoyne et al., 2007).

TABELA 3 - propriedades físicas das FB e da FV.

TABELA 4 - Valores de massa específica, frações volumétricas de fibra e matriz e volume de vazio dos cilindros do compósito epóxi/FB e epóxi/FV. 26

TABELA 5 - Comparação entre a análise semi-quantitativa de teor de óxidos de FB e composição da FB por Artemenko (2003).

TABELA 6 - Propriedades experimentais das placas do compósito epóxi/FB na direção longitudinal $\left(0^{\circ}\right)$ e transversal $\left(90^{\circ}\right)$. 29

TABELA 7 - Comparação entre as propriedades mecânicas experimentais da placa dos compósitos epóxi/FB, e epóxi/FV por Leitão (2008). 29

TABELA 8 - Resistência à tração aparente e resistência à tração aparente específica de ruptura do anel dos compósitos epóxi/FB e epóxi/FV. 30

TABELA 9 - Comparação entre resistência ao cisalhamento por viga (ILSS) curta para os compósitos de epóxi/FB e epóxi/FV. 34

TABELA 10 - Comparação entre pressão de ruptura dos cilindros de compósito de epóxi/FB e epóxi/FV submetidos ao ensaio hidrostático. 35 


\section{Lista de abreviações e símbolos}

FB - fibras de basalto

FV - fibras de vidro

epóxi/FB - material compósito polimérico reforçado com fibra de basalto

epóxi/FV - material compósito polimérico reforçado com fibra de vidro

MEV - microscopia eletrônica de varredura

FRX - Fluorescência de raios $X$

ILSS - resistência ao cisalhamento interlaminar

CNC - controle numérico computadorizado

$\mathrm{T}_{\mathrm{g}}$ - temperatura de transição vítrea

$v_{f}-$ fração volumétrica de fibra

$v_{m}$ - fração volumétrica de matriz

$v_{v}$ - fração volumétrica de vazios

$\mathrm{d}_{\mathrm{c}}$ - massa específica do compósito

$\mathrm{R}$ - resistência ao cisalhamento interlaminar

$\sigma$ - tensão de ruptura 


\section{SUMÁRIO}

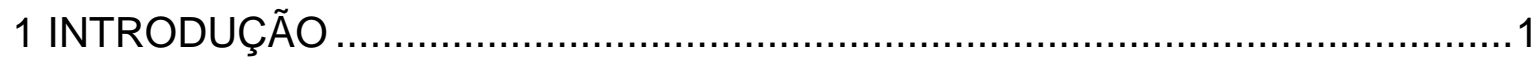

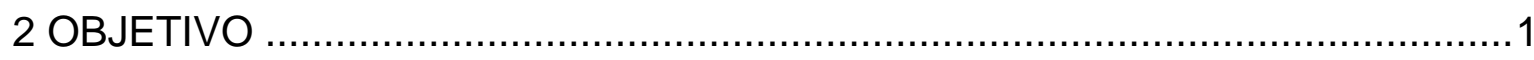

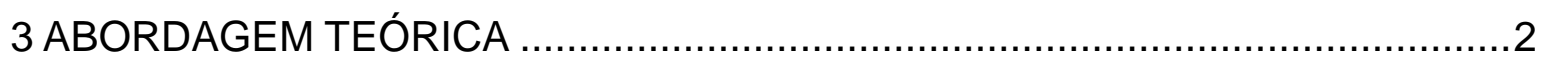

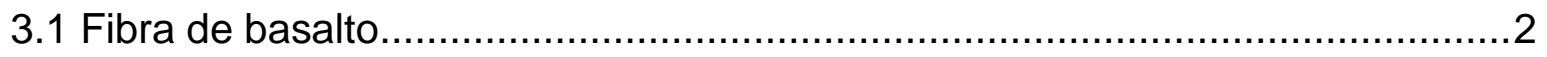

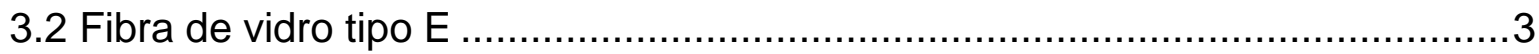

3.3 Propriedades e aplicações da fibra de basalto .......................................... 4

3.4 Técnica de enrolamento filamentar (filament winding) ..............................

3.4.1 Impregnação no enrolamento filamentar ...........................................

3.5 Código de identificação das camadas de um compósito................................9

3.6 Análise de falha em materiais compósitos laminados ...............................11

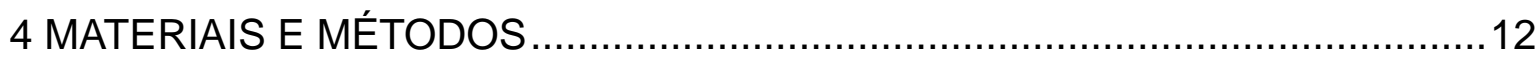

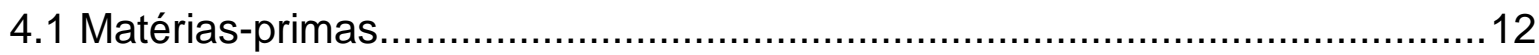

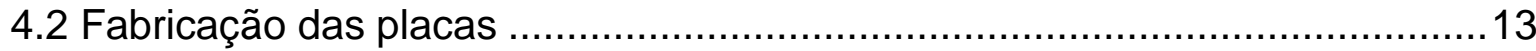

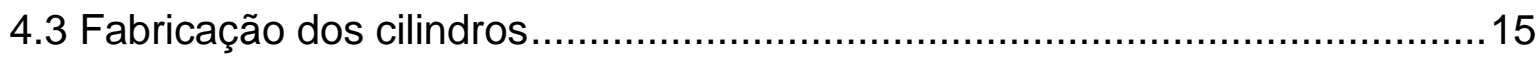

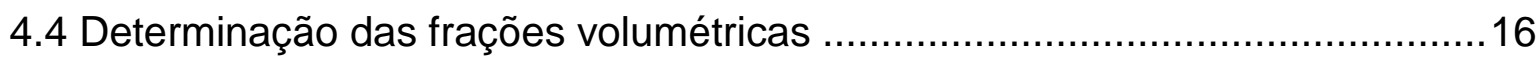

4.4.1 Determinação de frações volumétricas por queima da matriz ....................17

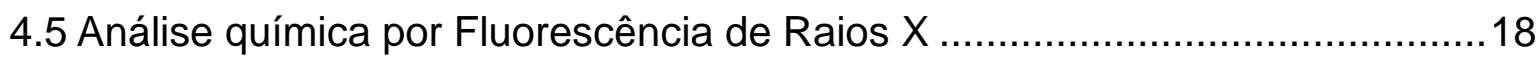

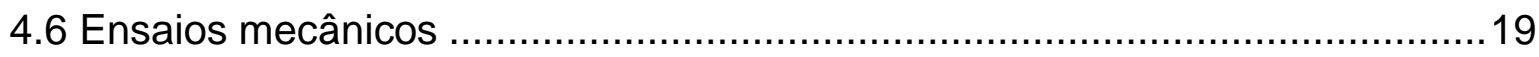

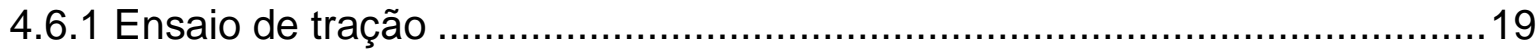

4.6.2 Ensaio de ruptura de anel (split disk) ............................................... 19

4.6.3 Resistência ao cisalhamento interlaminar (ILSS) ................................20

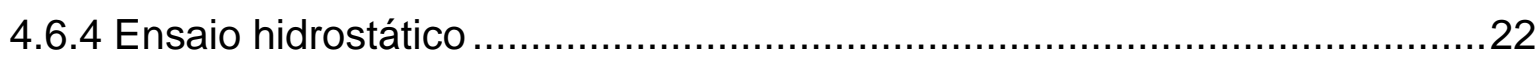

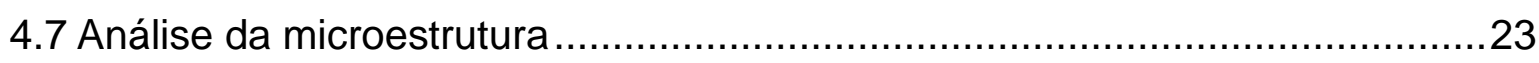

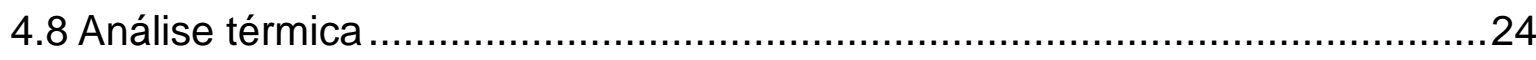

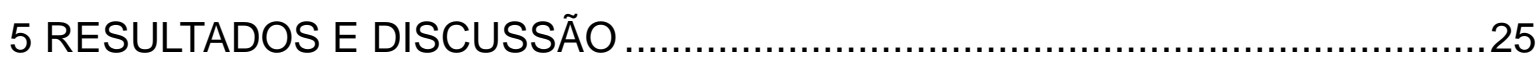

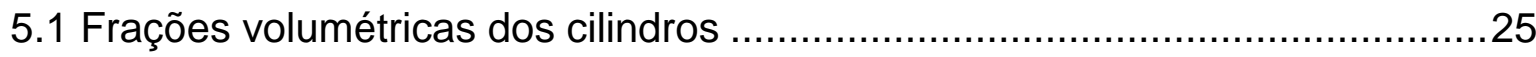

5.1.1 Frações volumétricas por massa específica e queima da matriz ................25

5.2 Análise por Fluorescência de Raios X (FRX) ….....................................27 


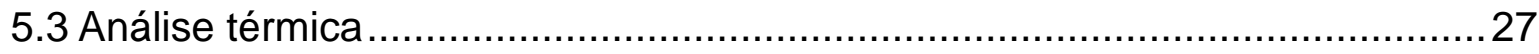

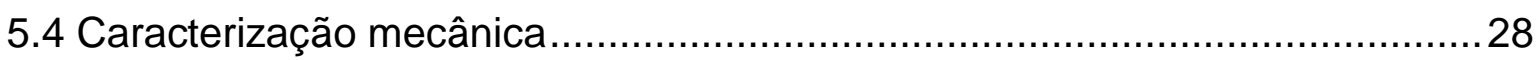

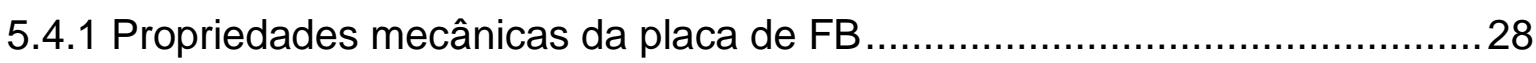

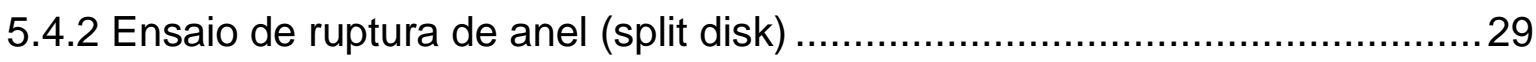

5.4.3 Resistência ao cisalhamento interlaminar (ILSS) ....................................... 33

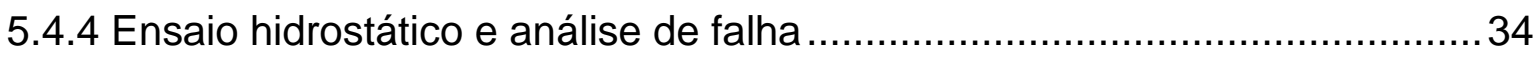

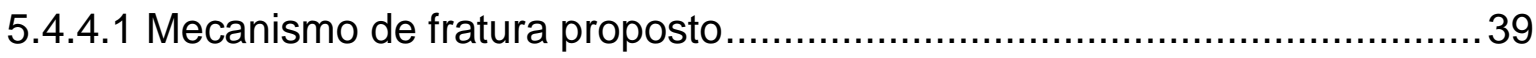

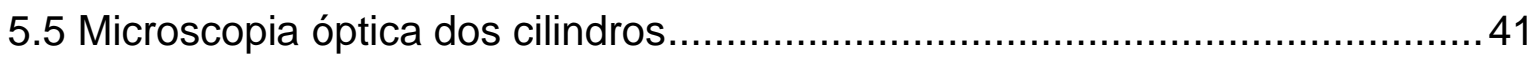

5.6 Microscopia eletrônica de varredura (MEV) dos cilindros ............................... 42

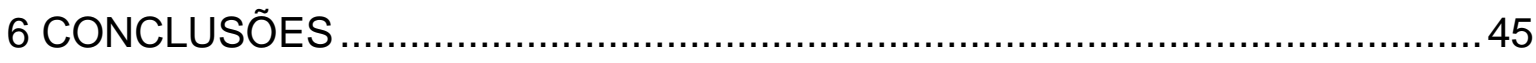

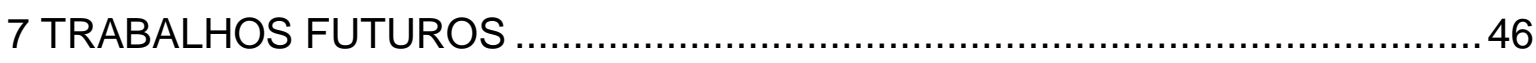

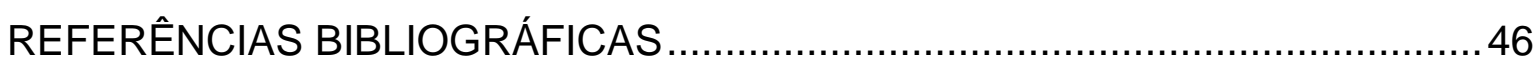




\section{INTRODUÇÃO}

Estruturas cilíndricas de material compósito fabricadas pela técnica de enrolamento filamentar são obtidas para uso em diversas aplicações estruturais: tanques, reservatórios de gás, tubos, carcaças de motores de foguetes, cascos cilíndricos, etc. Alta resistência mecânica e baixa massa específica são características que tornam a classe dos materiais compósitos poliméricos especialmente interessante para aplicações na área de transportes, principalmente no setor aeroespacial.

Uma definição para compósito é a de um material feito por duas ou mais fases quimicamente diferentes que apresente na escala macroscópica uma interface que as separa. O intuito da produção de um material compósito é geralmente obter uma combinação entre as propriedades de seus constituintes.

As fibras de basalto (FB) possuem diversas semelhanças com as fibras de vidro (FV), o que as torna competitivas com estas já tradicionalmente usadas como reforço em compósitos. Exemplos disso são composição química e massa específica semelhantes, propriedades mecânicas, resistência química, processo produtivo e custo, além de superá-las em certas propriedades - em especial, quanto a resistência à água e à estabilidade química. Apresentam excelente resistência a álcalis, propriedade semelhante às $\mathrm{FV}$, a um custo muito menor que as fibras de carbono e aramídicas. Suas propriedades térmicas as tornam possíveis substitutas de fibras resistentes a altas temperaturas (fibras de carbono), sendo comumente usadas na fabricação de escudos de calor, barreiras isolantes térmicas e artigos para proteção ao fogo - a temperatura de início de decomposição ao ar (na presença de oxigênio) das FB é de $205^{\circ} \mathrm{C}$ contra $163^{\circ} \mathrm{C}$ para as FV (Hao et al. 2010).

\section{OBJETIVO}

O presente estudo tem por objetivo executar ensaios hidrostáticos em tubos fabricados pelo prcesso de enrolamento filamentar utilizando a fibra de basalto e fibra de vidro, como também e analisar a falha e fratura de fragmentos dos cilindros após o colapso utilizando microscopia óptica e eletrônica de varredura. 
Apresenta como objetivos secundários a caracterização mecânica de placas planas também por enrolamento filamentar, determinação da resistência a tração de anéis retirados dos cilindros (split disk) e a resistência ao cisalhamento interlaminar (ILSS) de segmentos cilíndricos.

\section{ABORDAGEM TEÓRICA}

\subsection{Fibra de basalto}

O basalto é um mineral de origem vulcânica, escuro ou negro. Suas rochas são pesadas, tenazes e resistentes. Sua densidade é aproximadamente $5 \%$ maior que a do vidro. É a rocha mais abundante da crosta terrestre e o fundo dos oceanos é predominantemente composto de basalto. Na TAB. 1 é mostrada a composição química do basalto, que é variável de acordo com a jazida mineral utilizada.

TABELA 1 - Porcentagem em massa (intervalo) dos óxidos constituintes da FB e da FV tipo E.

\begin{tabular}{lcc}
\hline $\begin{array}{c}\text { Constituinte } \\
\text { (\% em massa) }\end{array}$ & Fibra de basalto* & ${\text { Fibra de vidro tipo } \mathbf{E}^{* *}}^{*}$ \\
\hline $\mathrm{SiO}_{2}$ & $48,8-51,0$ & 55,2 \\
$\mathrm{Al}_{2} \mathrm{O}_{3}$ & $14,0-15,6$ & 8,0 \\
$\mathrm{CaO}$ & 10,0 & 18,7 \\
$\mathrm{MgO}$ & $6,2-16,0$ & - \\
$\mathrm{FeO}+\mathrm{Fe}_{2} \mathrm{O}_{3}$ & $7,3-13,3$ & 7,3 \\
$\mathrm{~B}_{2} \mathrm{O}_{3}$ & - & - \\
$\mathrm{TiO}_{2}$ & $0,9-1,6$ & - \\
$\mathrm{MnO}$ & $0,10-0,16$ & 0,5 \\
$\mathrm{Na}_{2} \mathrm{O}+\mathrm{K}_{2} \mathrm{O}$ & $1,9-2,2$ & \\
\hline & &
\end{tabular}

A utilização de FB como reforço em materiais compósitos de matriz polimérica é relativamente nova, quando comparada às populares FV e de 
carbono. As primeiras tentativas de se produzir FB remetem ao ano de 1923, quando o francês Paul Dhé registrou, nos EUA, a primeira patente de filamentos contínuos de basalto. Após a Segunda Guerra Mundial pesquisas foram desenvolvidas nos EUA, Europa e União Soviética para obterem-se fibras extrudadas e, em tal época, as primeiras aplicações nas áreas militar e aeroespacial foram pesquisadas. Apenas após 1990/92, com a dissolução da União Soviética, sua tecnologia produtiva passou a ser de domínio público, e assim se deu o início às pesquisas civis (Colombo et al., 2012).

A produção de fibras foi, no entanto, apenas desenvolvida nas últimas décadas. A tecnologia para produzir a FB é muito semelhante a empregada na produção das $F V$, e considerando ainda a grande disponibilidade de matériaprima, compõem fatores que favorecem o preço competitivo da FB em relação às FV. A principal diferença entre as FB e as FV encontra-se nas matérias-primas utilizadas. A FV é produzida a partir de vários componentes, enquanto que a FB é feita com a fusão da rocha de basalto, sem outros aditivos.

O processo produtivo das FB é iniciado com a trituração da rocha de basalto, posterior lavagem, para então ser transportada até banhos de fusão em fornos aquecidos por gás, a temperaturas entre $1460{ }^{\circ} \mathrm{C}$ e $1500{ }^{\circ} \mathrm{C}$. O basalto fundido flui através de um banho de platina-ródio com 200, 400, 800 ou mais furos, e as fibras podem ser puxadas do fundido sob pressão hidrostática. Após isso, um sizing é aplicado à superfície das fibras, conferindo às mesmas integridade, lubricidade e compatibilidade com a resina (Fazio, 2011).

O fato de serem ecologicamente corretas torna a utilização das FB muito atraente. Ao contrário das FV, as FB não requerem aditivos em sua fabricação. A substituição de FV por FB pode reduzir o risco de poluição ambiental com metais e óxidos de altamente tóxicos, os quais são gerados na produção das FV (Parnas et al., 2007). Ainda, as FB de basalto são uma alternativa às fibras de asbestos, banidas por serem carcinogênicas.

\subsection{Fibra de vidro tipo $E$}

As FV comuns possuem sílica como componente majoritário - assim como a fibra de basalto - além de uma série de outros óxidos. Comercialmente, são encontradas em uma variedade de composições. A designação "tipo E" da FV 
se refere às boas propriedades de isolamento elétrico do vidro tipo $E$; sua composição é mostrada na TAB. 1. Outros exemplos de tipos de FV disponíveis: tipo $\mathrm{C}$, resistente à corrosão porque o vidro tipo $\mathrm{C}$ tem melhor resistência à corrosão química, e a tipo $\mathrm{S}$ com alto teor de sílica que faz com que o vidro tipo $\mathrm{S}$ resista a maiores temperaturas que outros vidros (Chawla, 2001).

Compósitos que utilizam FV como reforço têm uma ampla aceitação e utilização no mundo. É importante notar que existem várias limitações para esse grupo de materiais. Apesar de possuírem resistências elevadas, as FV apresentam um módulo de elasticidade considerado baixo para aplicações estruturais e não oferecem a resistência necessária para algumas aplicações, como por exemplo, em elementos estruturais para aplicações aeronáuticas e pontes. Como já citado, a temperatura de utilização da FV na presença de oxigênio é em torno de $160^{\circ} \mathrm{C}$, que se encontra próxima do limite das resinas termofixas utilizadas na fabricação de compósitos. As temperaturas de serviço podem ser estendidas até aproximadamente $300{ }^{\circ} \mathrm{C}$ pelo uso de sílica fundida de alta pureza para as fibras e com polímeros resistentes a altas temperaturas, como as poli-imidas, por exemplo (Callister, 2000).

\subsection{Propriedades e aplicações da fibra de basalto}

As FB são altamente competitivas em relação às $\mathrm{FV}$, principalmente em comparação às propriedades mecânicas, como mostrado na TAB. 2, além de superá-las em certas propriedades - em especial, quanto a resistência à água e à estabilidade química. Em diversas formas de apresentação, seja como filamentos torcidos e não-torcidos, novelos, tecidos ou mantas, as FB representam uma alternativa promissora como elemento de reforço para materiais compósitos. 
TABELA 2 - Comparação entre as propriedades das fibras (Colombo et al., 2012. In: Burgoyne et al., 2007).

\begin{tabular}{cccc}
\hline & Basalto & Vidro-E & Carbono \\
\hline Resistência à tração (MPa) & 4840 & 3450 & 3500 \\
Módulo de elasticidade (GPa) & 89 & 72,4 & 240 \\
Deformação de ruptura (\%) & 3,1 & 4,7 & 1,25 \\
\hline
\end{tabular}

A aplicação das FB é possível em diversas áreas graças às suas múltiplas e boas propriedades. Apresentam excelente resistência à álcalis, propriedade semelhante às $\mathrm{FV}$, a um custo muito menor que as fibras de carbono e aramídicas. $\mathrm{O}$ amortecimento de vibrações das FB é muito maior que o das FV, o que as tornaram adequadas para aplicações sob altas vibrações e cargas acústicas, como em estruturas onde existam tais condições, por exemplo, na indústria aeronáutica e indústria naval (Fazio, 2011). Sua alta resistência à água também justifica a grande aplicação na indústria naval, como na produção de cascos de embarcações. Por suas boas propriedades de isolamento elétrico (10 vezes maior que o vidro) (Parnas et al., 2007; Singha, 2012), as FB são usadas em placas de circuitos impressos, em isolamento extra-fino para cabos elétricos e em dutos subterrâneos. Quanto às propriedades mecânicas, mostradas na TAB. 2, de módulo e resistência à tração, a FB supera a FV-E em torno de $11 \%$ (em resistência) e 15\% (em módulo).

Uma das possíveis aplicações das FB é na fabricação de cilindros de armazenamento de gás natural. A fabricante de FB Kamenny Vek realizou uma série de ensaios com o objetivo de comparar as propriedades mecânicas de cilindros de compósito de matriz epóxi reforçados com FB, FV-E ou fibra de carbono, utilizando-se a técnica de enrolamento filamentar. Um possível método de fabricação destes cilindros usa um liner metálico como molde (mandril), o qual recebe um reforço em sua superfície externa, a partir da bobinagem do filamento de FB impregnado de resina epóxi, conforme ilustração na FIG. 1 (www.basfiber.com, 2014). 


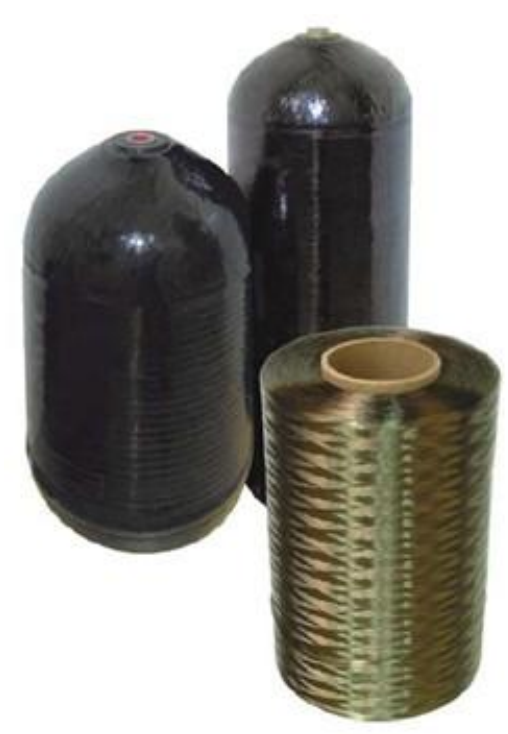

FIGURA 1 - Cilindro de armazenamento de gás natural reforçado com epóxi/FB e novelo de filamento de FB (www.basfiber.com, 2014).

Com o propósito de investigar a utilização de FB na fabricação de cilindros de gás natural, Pavlovsky et al. (2007) desenvolveram um estudo onde foi analisada a resistência a tração e módulo de elasticidade de corpos-de-prova em formato de anel feitas com epóxi/FB, epóxi/FV-E e epóxi/fibra de carbono, conforme ilustra a FIG. 2 O processo de enrolamento filamentar foi utilizado na confecção dos corpos-de-prova que apresentaram fração volumétrica de fibra em torno de $65 \%$. Os resultados dos ensaios mostraram valores de resistência à tração e módulo de elasticidade para epóxi/FB: 2937 MPa, 109 GPa; epóxi/FV-E: $2586 \mathrm{MPa}, 74.4 \mathrm{GPa}$ e epóxi/fibra de carbono: $4881 \mathrm{MPa}, 231 \mathrm{GPa}$.

Comparando-se com os corpos-de-prova de epóxi/FV-E, os valores foram respectivamente $13 \%$ e $46 \%$ maiores. Em relação às de epóxi/fibra de carbono, os resultados de resistência a tração e módulo de elasticidade foram $40 \%$ e 53\% menores. Contudo, considerando-se que a fibra de carbono apresenta aproximadamente o dobro da resistência à tração e do módulo de elasticidade e uma relação de custo que pode ser oito vezes maior, o compósito de epóxi/fibra de carbono ainda não seria muito atrativo na fabricação de cilindros de armazenamento de gás natural. De acordo com os cálculos do estudo dos autores, seria possível fabricar cilindros de epóxi/FB com a mesma resistência à tração que aqueles fabricados de epóxi/FV, porém com redução de peso em torno de $15 \%$ e de custo em $5 \%$. 


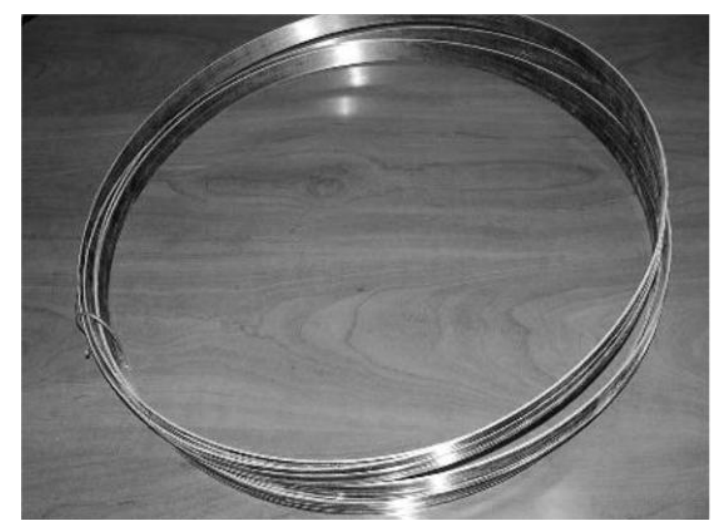

FIGURA 2 - Corpos-de-prova em formato de anel compósito de fibra de basalto (Pavlovsky et al., 2007).

\subsection{Técnica de enrolamento filamentar (filament winding)}

O maior aproveitamento das propriedades das fibras utilizadas como reforço contínuo ocorre quando as mesmas são solicitadas em sua direção longitudinal. A técnica do enrolamento filamentar (filament winding) se destaca como o processo de fabricação que melhor aproveita esta vantagem. Componentes fabricados por esse processo têm como objetivo conseguir uma das mais altas relações resistência-peso entre os materiais empregados para aplicações estruturais. Entretanto, para garantir esse resultado, é necessário que a orientação da fibra esteja na direção das tensões principais de tração, e que ao mesmo tempo se utilize uma fração de reforço na matriz proporcional à magnitude dessas tensões (Marinucci, 2011).

O enrolamento filamentar consiste na deposição de filamentos contínuos impregnados com resina sobre um molde ou cilindro giratório, com o uso de um torno CNC (controle numérico computadorizado). As bobinas de fibra são colocadas em um porta-bobinas que possuem controle de tensão dos filamentos. Estes são liberados e passam por um banho de matriz (resinaendurecedor-acelerador) aquecido, equipado com um controle de temperatura. $\mathrm{O}$ molde permanece na posição horizontal e gira puxando o filamento, enquanto o sistema de aplicação de fibra tem um deslocamento longitudinal paralelo ao eixo do mandril. Uma nomenclatura é dada de acordo com a maneira que a deposição da fibra é realizada: enrolamento circunferencial, quando a fibra é depositada perpendicularmente ao eixo de rotação do molde; enrolamento helicoidal, com 
deposição em formato de hélice; enrolamento polar, quando o sistema de deposição é projetado para realizar rotação em torno do cilindro do molde. Os parâmetros de bobinagem, tais como tensão no filamento, velocidade angular do molde e velocidade do sistema de aplicação de fibra longitudinal, são controlados pelo CNC. O movimento coordenado desses dois eixos estabelece os ângulos de deposição da fibra sobre o mandril. Uma ilustração de um equipamento de enrolamento filamentar de dois graus de liberdade é mostrada na FIG. 3. É recomendado que $\mathrm{o}$ ambiente de produção tenha temperatura e umidade controladas.

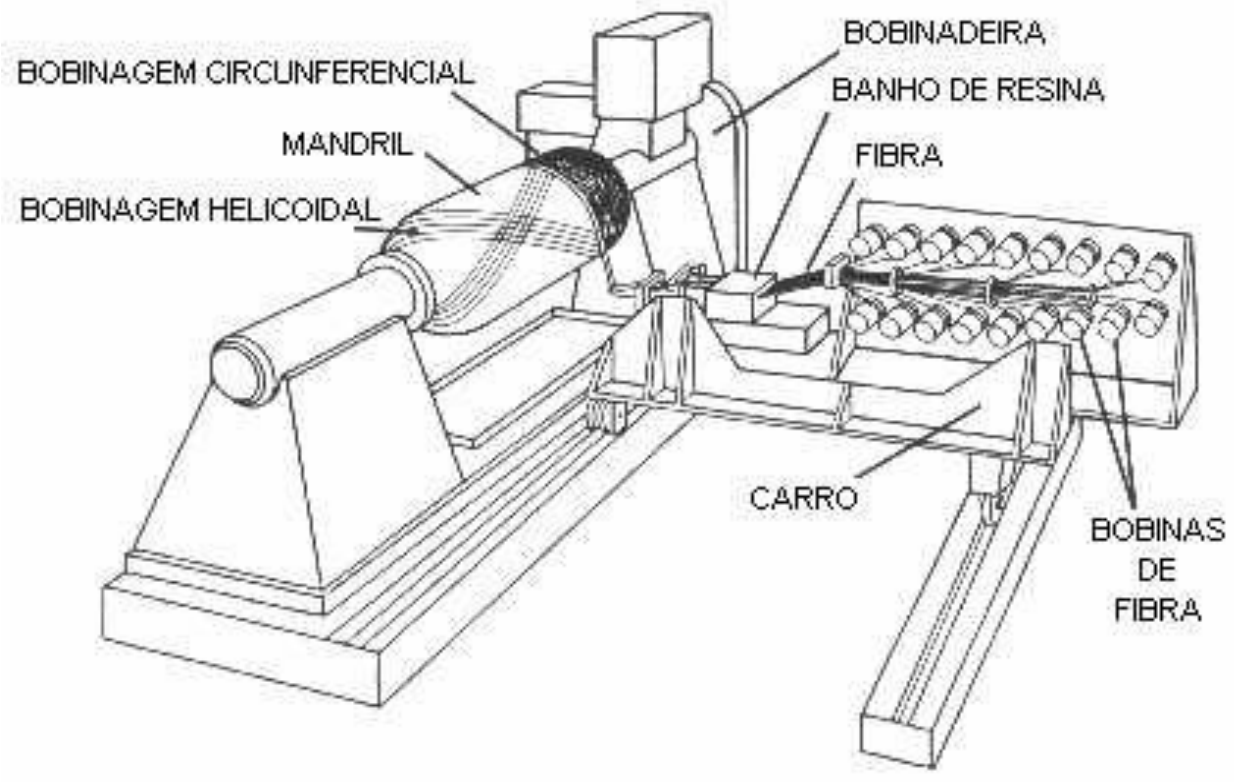

FIGURA 3 - Máquina de enrolamento filamentar (Strong, 1989). 
O enrolamento filamentar é utilizado principalmente para fabricar peças que tenham uma simetria de revolução. Tubos, tanques, botijões de gás, cascos de cilindros, foguetes e mísseis estão entre as estruturas fabricadas por esse processo. Outras características deste processo que se podem destacar são a possibilidade de se obter frações volumétricas elevadas de fibras (60 a 75\%), possibilidade de fabricar peças de grande porte e de se produzir estruturas lisas por dentro e requerer ainda pouca mão de obra, com grande possibilidade de automação. Algumas limitações do processo estão associadas ao investimento relativamente alto, limitação no formato das peças (sem concavidades) e exigência de mão de obra qualificada (Cauchois, 2009).

Os parâmetros de produção alta tensão no fio e tempo de enrolamento curto produzem peças com maior fração volumétrica de fibras. O mecanismo pelo qual isso ocorre é relacionado com o deslocamento da fibra através da resina. Ambos parâmetros (alta tensão e baixa viscosidade) provocam maior deslocamento da fibra e, dessa forma, maior compactação que leva a um maior volume de fibras (Cohen, 1997).

\subsubsection{Impregnação no enrolamento filamentar}

O termo impregnação significa unir o reforço à resina. Dois principais métodos de impregnação são usados no enrolamento filamentar: enrolamento por via seca e por via úmida. No enrolamento por via seca bobinas contendo fibras pré-impregnadas (bobinas de prepegs) são enroladas diretamente sobre a superfície do molde, enquanto que no enrolamento por via úmida, a impregnação é realizada utilizando banho dosador ou com rolo dosador.

$\mathrm{Na}$ impregnação utilizando banho, a fibra passa por dentro de uma cuba contendo a matriz polimérica, sendo que o comprimento da cuba está associado à velocidade de passagem da fibra de modo a garantir uma efetiva molhabilidade das fibras. Na utilização de um rolo impregnador a fibra movimenta por atrito um cilindro que passa em uma bandeja com resina, o que mantém o cilindro com resina sobre sua superfície para impregnar a fibra por contato.

\subsection{Código de identificação das camadas de um compósito}

Materiais compósitos laminados recebem um código que especifica o 
arranjo utilizado no empilhamento de suas camadas constituintes. Cada uma dessas camadas é identificada pelo ângulo que a fibra forma em relação ao eixo de referência. No caso de um cilindro produzido por enrolamento filamentar, o eixo longitudinal do molde é tomado como referência. A identificação da sequência de camadas na fabricação de um componente é feita normalmente utilizando-se o código padrão de laminação ou standard lamiante code, como muitas vezes é conhecido.

O código é construído de modo que a leitura é feita da esquerda para direita, sendo o primeiro valor à esquerda referente à primeira camada e o último à direita o da última camada. Considerando a orientação das camadas, estas quando posicionadas no sentido horário, é atribuído um valor negativo do ângulo, e valores positivos para camadas no sentido anti-horário. Como exemplo, a configuração dos cilindros fabricados no presente estudo é $\left[90_{2} /-30 /+30 / 90_{2}\right]$ T. Assim, a identificação mostra que a terceira camada será bobinada no sentido horário e a seguinte no sentido anti-horário. O subscrito "T" indica que as camadas representadas no código se referem ao número total de camadas utilizadas nessa fabricação.

Camadas posicionadas a $90^{\circ}$ por enrolamento filamentar são geralmente denominadas como circunferenciais, e camadas com ângulos agudos de deposição são denominadas helicoidais. $\mathrm{Na}$ configuração dos cilindros, o subscrito "2" junto ao ângulo indica o número de camadas adjacentes, ou seja, na direção $90^{\circ}$ são colocadas duas camadas com essa orientação. Desse modo, os cilindros terão um total de 6 camadas. Uma ilustração do empilhamento das camadas dos compósitos fabricados neste trabalho e seu respectivo código de identificação é mostrado na FIG.4. 


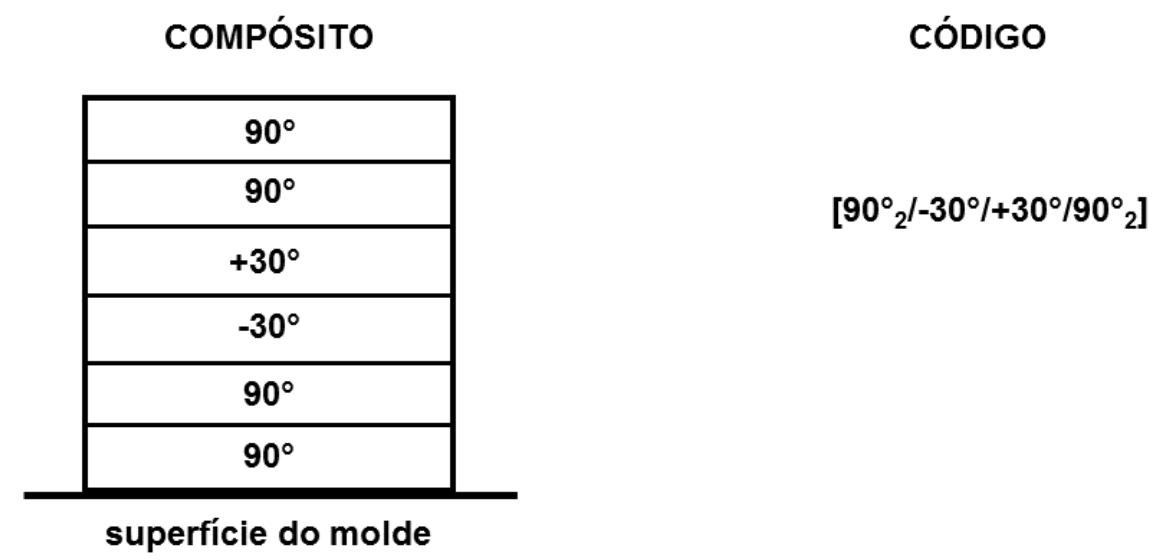

FIGURA 4 - Compósito laminado e seu código de identificação.

\subsection{Análise de falha em materiais compósitos laminados}

Investigar a fratura de um componente produzido com material compósito pode revelar informações sobre as propriedades do material, como resistência da interface fibra-matriz, assim como informações a respeito dos modos de falha envolvidos. De forma geral, a fratura será governada por um ou uma combinação de mecanismos envolvendo a camada do laminado, como ilustrado na FIG. 5. A falha em compósitos laminados pode ser classificada pela sua orientação no mesmo, em três modos básicos: interlaminar, intralaminar e translaminar. Greenhalgh (2009) as descreve da seguinte maneira: a falha interlaminar (ou delaminação) ocorre no plano do laminado, no qual camadas são separadas; a falha intralaminar ocorre através da espessura do laminado na qual a matriz ou o intervalo fibra-matriz é rompido e a falha translaminar se dá através da espessura do laminado, com rompimento de fibras. 


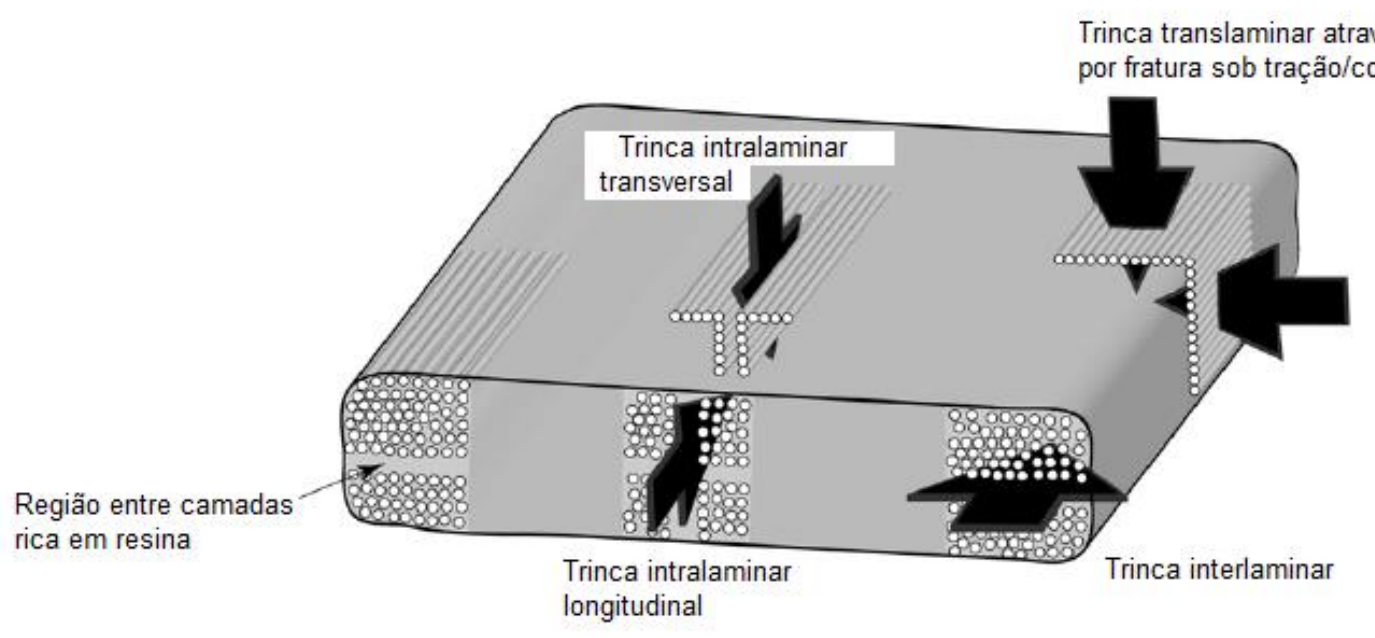

FIGURA 5 - Visão geral dos modos de falha em uma lâmina (Laffan et al., 2012).

\section{MATERIAIS E MÉTODOS}

\subsection{Matérias-primas}

Cilindros laminados de compósito reforçado com FV e FB com geometria cilíndrica com extremidades abertas foram produzidos pela técnica de enrolamento filamentar. Todos os cilindros foram produzidos usando um total de seis camadas depositadas com a configuração de bobinagem $\left[90^{\circ}{ }_{2} /-\right.$ $\left.30 \%+30 \% 90^{\circ}{ }_{2}\right]_{\mathrm{T}}$.

A FB a ser utilizada neste trabalho foi fornecida na forma de um filamento contínuo, com densidade linear de 1200 tex, constituída com fios que apresentam diâmetro entre $10 \mu \mathrm{m}$ e $22 \mu \mathrm{m}$, com sizing de agente silano, compatível com resinas epóxi e fenólica. O material foi oferecido pela empresa russa Kamenny Vek para o desenvolvimento do presente estudo, haja vista que ainda não existe produção ou comercialização da fibra no país. A TAB. 3 relaciona propriedades físicas da FB (Kammeny Vek, 2014).

A FV utilizada também foi fornecida na forma de filamento contínuo, sendo constituída de vidro tipo E, com densidade linear de 2000 tex. O material foi oferecido pela empresa brasileira CPIC. O sizing aplicado também é de agente silano, compatível com as resinas epóxi e amina. A TAB. 3 relaciona propriedades físicas da FV (CPIC, 2014). 
TABELA 3 - propriedades físicas das FB e da FV.

\begin{tabular}{ccc}
\hline & FB & FV \\
\hline Diâmetro do monofilamento $(\boldsymbol{\mu m})$ & $10-22$ & - \\
Densidade linear (tex) & 1200 & 2000 \\
Tipo de sizing & agente silano & agente silano \\
Fração de sizing $(\%$ em massa) & $\geq 0.4$ & - \\
Massa específica $\left(\mathbf{g} / \mathbf{c m}^{3}\right)$ & 2,66 & 2,6 \\
\hline
\end{tabular}

*(Kammeny Vek, 2014).

${ }^{* *}$ (CPIC, 2014).

A matriz polimérica escolhida é um sistema tricomponente que consiste de resina epoxídica, endurecedor e acelerador, com $\mathrm{T}_{g}$ acima de $100{ }^{\circ} \mathrm{C}$, com temperatura final de cura de $150^{\circ} \mathrm{C}$ e com viscosidade e tempo de gel adequados à fabricação de peças cilíndricas pelo processo de enrolamento filamentar. A constituição química desses componentes e suas proporções de mistura em massa utilizadas foram: resina epóxi- éter diglicidílico de bisfenol A (100 partes em massa); endurecedor- metiltetrahidroftálico (88 partes em massa); e aceleradorbenzildimetilamina ( 0,5 parte em massa).

Essas duas fibras utilizadas na fabricação dos cilindros foram fornecidas em arranjos diferentes pelos fabricantes. Enquanto que a FB é enrolada na superfície de um carretel em formato de tubo que permite o encaixe na máquina bobinadeira, a FV é fornecida enrolada sem carretel, em torno de si própria, para desenrolamento interno. A máquina bobinadeira funciona utilizando carretéis de fibra, como foi descrito no caso da FB. Com isso, fez-se necessário enrolar manualmente as FV em novelo para aproveitarmos as vantagens do processo automático de liberação de fibras pela bobinadeira, além de manter padronizado o processo produtivo dos cilindros para os dois tipos de fibra.

\subsection{Fabricação das placas}

Para a fabricação das placas unidirecionais de compósito reforçado com fibra de basalto utilizou-se um molde metálico de seção retangular e 
aquecimento interno a $60{ }^{\circ} \mathrm{C}$. O molde foi coberto com filme adesivado impermeável para facilitar a desmoldagem. $O$ processo de enrolamento filamentar para uma placa de FB é mostrado na FIG. 6.

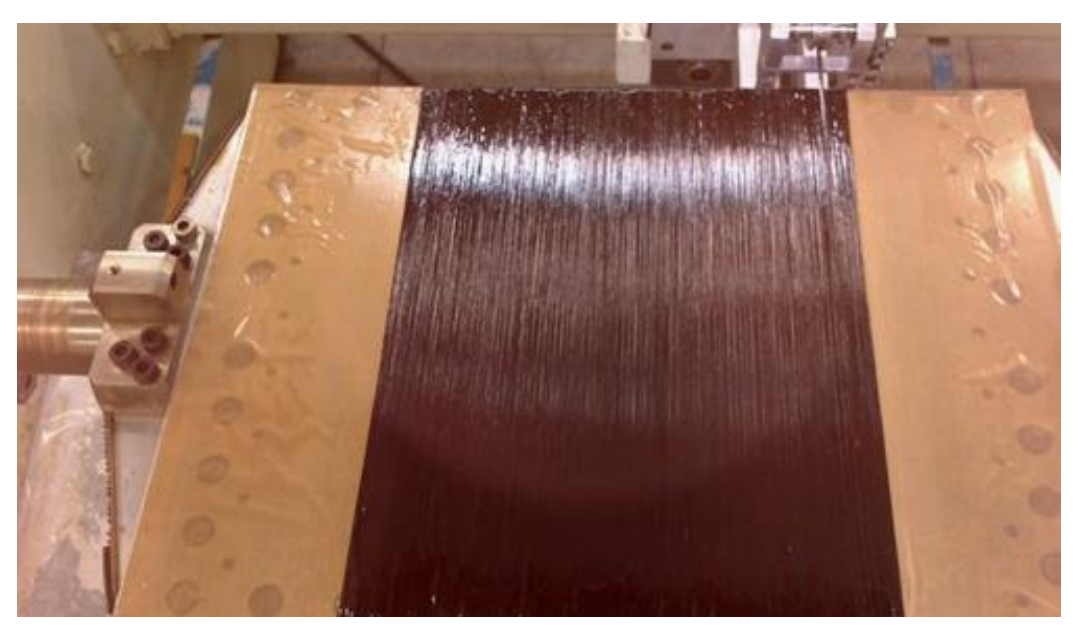

FIGURA 6 - Fabricação da placa de compósito reforçado com FB.

Após o processo, o molde é prensado em ambos os lados por placas de aço de superfície plana e polida denominadas placas de prensagem (caul plates), providas de parafusos fixados por batentes em suas extremidades. As placas são produzidas de acordo com a norma ASTM D3039/D3039M (2014), com espessura de 1 ou $2 \mathrm{~mm}$, de acordo com o tipo de batente utilizado. $\mathrm{O}$ conjunto molde-placas de prensagem é levado à estufa para cura a $150^{\circ} \mathrm{C}$ por 8 $\mathrm{h}$, seguido de resfriamento lento. As placas de espessura de $1 \mathrm{~mm}$ foram laminadas com a configuração $\left[0^{\circ}\right]_{\mathrm{T}}$, e as de espessura $2 \mathrm{~mm}$ com $\left[0^{\circ}{ }_{8}\right]_{\mathrm{T}}$. Molde e banho de resina são mantidos a mesma temperatura durante o processo de enrolamento.

Foi realizada a colagem de tabs em todos corpos-de-prova, usando material compósito com propriedades semelhantes aos compósitos avaliados. Os corpos-de-prova para ensaio na direção longitudinal $\left(0^{\circ}\right)$ foram cortados da placa de $1 \mathrm{~mm}$ de espessura, com serra contendo disco diamantado, nas dimensões $250 \times 15 \times 1 \mathrm{~mm}$, total de 5 corpos-de-prova; para o ensaio na direção transversal $\left(90^{\circ}\right)$, foram cortados da placa de espessura de $2 \mathrm{~mm}$, nas dimensões $175 \times 25 \times$ $2 \mathrm{~mm}$, total de 5 corpos-de-prova. A finalidade dos tabs é proteger os corpos-deprova de eventuais danos no mordente da máquina de tração. 


\subsection{Fabricação dos cilindros}

O processo de fabricação dos componentes cilíndricos a serem avaliados foi realizado de acordo com as etapas descritas a seguir. Os parâmetros de fabricação foram definidos baseando-se nos estudos de Carvalho (2006) e Marinucci (2001) para aproveitar o conhecimento desenvolvido nestes trabalhos, assim como para possibilitar comparações de resultados, muito embora tais trabalhos tenham utilizado compósito de fibra de carbono/epóxi. Nesse contexto, escolheu-se a técnica de fabricação de cilindros com extremidades abertas por enrolamento filamentar, o tipo de molde utilizado no processo (molde de alumínio com aquecimento interno), domos pinados para suporte dos filamentos enrolados na direção helicoidal e parâmetros de bobinagem, tais como tensão no filamento, velocidade angular do molde e velocidade do carro longitudinal, que foram controlados pelo CNC. Ainda na fabricação dos componentes foi utilizado: estufa de cura com mancais rotativos - ciclo de cura de $8 \mathrm{~h}$ a $150{ }^{\circ} \mathrm{C}$ e torno universal equipado com retificadora de alta rotação e disco de corte diamantado, para usinagem das extremidades.

Um total de 3 cilindros em FB e 3 cilindros em FV foram produzidos e de cada deles, foram retirados, 2 corpos-de-prova para ensaio de ruptura de anel (split disk), 2 para determinação da resistência ao cisalhamento interlaminar (ILSS) e 6 para massa específica e frações volumétricas.

Nas etapas de enrolamento helicoidal, de ângulos $-30^{\circ} \mathrm{e}+30^{\circ}$, utilizou-se domos pinados fixados nas extremidades do molde para permitir 0 ancoramento da fibra no momento de reversão dos movimentos do carro e do molde, adotando-se o método de superposição de camadas, ao contrário do método que forma cruzamentos das fibras, comumente conhecido como interweaving. A FIG. 7 mostra o processo de fabricação de um cilindro reforçado com FB durante a deposição de uma camada $-30^{\circ}$. 


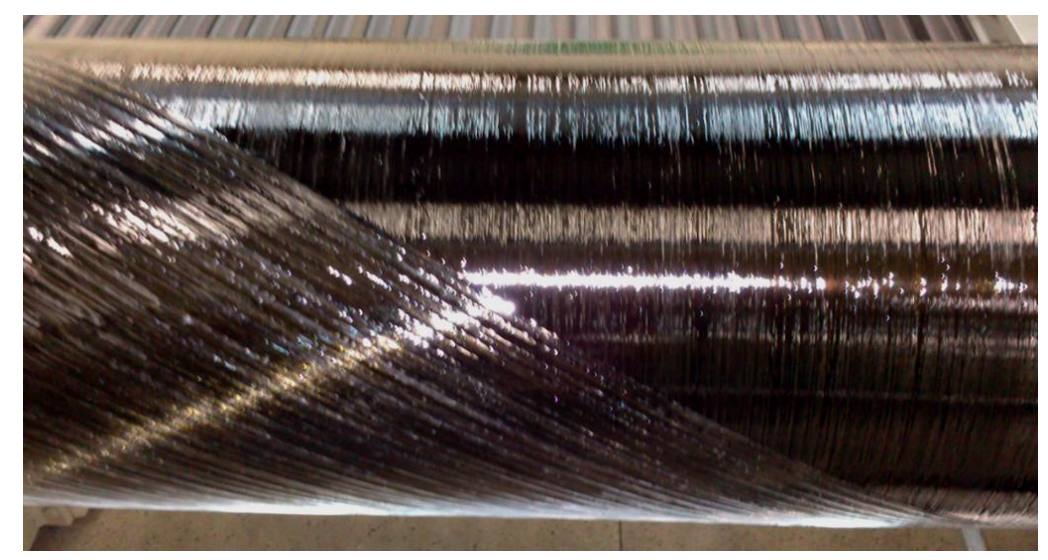

FIGURA 7 - Produção do cilindro reforçado com FB.

A definição da configuração das camadas depositadas no processo de enrolamento filamentar levou em consideração estudos semelhantes presentes na literatura, a resistência do cilindro nas direções longitudinal e transversal, o número de camadas depositadas e os limites operacionais de segurança do dispositivo de ensaio hidrostático. Uma das funções das camadas circunferenciais é conferir resistência e rigidez nesta direção, principalmente em vista do fato do ensaio hidrostático utilizado ser unidirecional na direção circunferencial. Outra função apontada por Cohen (1995) é que as camadas circunferenciais $\left(90^{\circ}\right)$ ajudam a compactar as camadas helicoidais, que possuem baixa pressão de compactação radial devido ao seu ângulo agudo de deposição.

\subsection{Determinação das frações volumétricas}

A obtenção de peças de compósitos de alto desempenho requer que 0 processo de fabricação e o ciclo de cura criem estruturas de alta qualidade, com baixa porosidade. Quando poros estão presentes, o desempenho do compósito será significativamente reduzido. Isto é geralmente percebido por reduções significativas em propriedades dominadas pela resina, com compressão e resistência ao cisalhamento. Poros em materiais compósitos são regiões com ausência de componentes dos compósitos: matriz e fibras. As regiões porosas em compósitos podem ser esféricas ou oblongas, mas outras morfologias complexas de poros podem ser observadas. É sabido que a morfologia dos poros e sua localização no compósito afeta significativamente suas propriedades mecânicas, assim como o tamanho, número e volume dos poros. Existem muitas causas de 
porosidade em compósitos, que são geralmente categorizadas por poros devido a voláteis (como água e solventes, por exemplo), ou poros resultantes de ar aprisionado. A formação dos poros e sua morfologia dependem dos materiais de das condições de processamento (ASM, 2010).

\subsubsection{Determinação de frações volumétricas por queima da matriz}

O método escolhido na determinação das frações volumétricas requer inicialmente a determinação da massa específica dos compósitos. Para isso, foi utilizado uma balança com precisão de $0,1 \mathrm{mg}$ e que dispõe de suporte para pesagem a seco e pesagem imersa, de acordo com a norma ASTM D792 (2013). Duas amostras de cada cilindro, com geometria retangular de $10 \mathrm{~mm} \times 20 \mathrm{~mm}$, com massa em torno de $2 \mathrm{~g}$, passaram por este procedimento. Na pesagem submersa, bolhas que podem aderir ao suporte e à amostra são removidas. Um termômetro é fixado no béquer com água para medição da temperatura. A massa específica do compósito $d_{c}$ é então calculada usando a equação (1):

$$
\mathrm{d}_{\mathrm{c}}=\left(\frac{\mathrm{p}_{\mathrm{s}}}{\mathrm{p}_{\mathrm{s}}-\mathrm{p}_{\mathrm{i}}}\right) \cdot \mathrm{d}_{\mathrm{a}}
$$

em que $p_{s}$ é a massa da amostra seca; $p_{i}$ é a massa da amostra imersa e $d_{a}$ é a densidade da água à temperatura durante a pesagem.

As frações em volume dos constituintes dos compósitos foram determinadas a partir da queima da matriz em mufla, baseando-se na norma ASTM D3171 (2015). Inicialmente, cadinhos cerâmicos são aquecidos em mufla a $565{ }^{\circ} \mathrm{C}$ por 10 min para retirada da umidade, e então resfriados em dessecador até temperatura ambiente para pesagem. Após essa etapa, cada amostra de massa específica previamente determinada é colocada em um cadinho para aquecimento controlado em um bico de Bunsen (FIG. 8) até cessar a queima da matriz. Por fim o cadinho é levado para mulfla a $565{ }^{\circ} \mathrm{C}$ até que todo material carbonoso desapareça (período de $2 \mathrm{~h}$ em mufla foi suficiente para as amostras do presente estudo). 


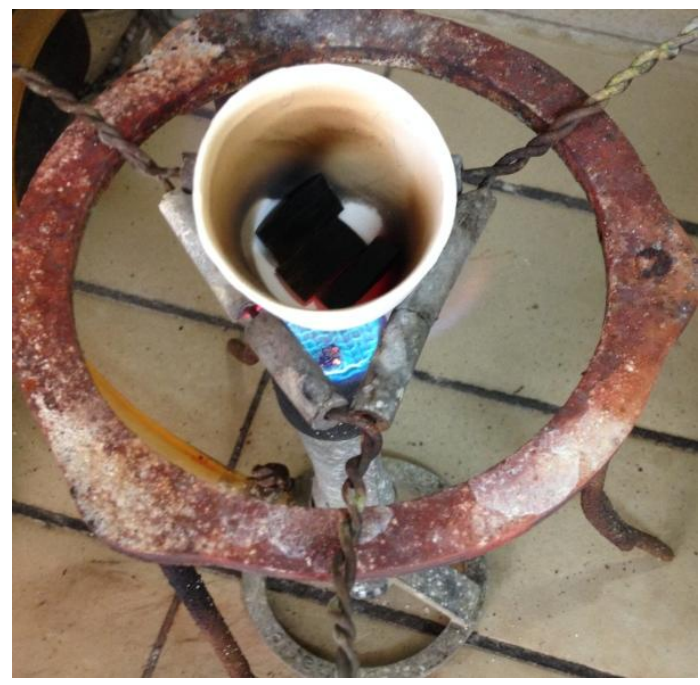

FIGURA 8 - Aquecimento de amostra do compósito epóxi/FB em bico de Bunsen.

Calculou-se as frações volumétricas de fibra $(\mathrm{Vf})$, de matriz $(\mathrm{Vm})$ e de vazios ( $v v$ ) através das equações (2), (3) e (4), sendo: $M_{f}$ - massa de fibra; $M_{a}-$ massa inicial da amostra; $d f$, - massa específica da fibra; $d m$ - massa específica da matriz e dc-massa específica do compósito.

$$
\begin{aligned}
& v_{f}=\left(\frac{M_{f}}{M_{a}}\right) \cdot\left(\frac{d_{c}}{d_{f}}\right) \cdot 100 \\
& v_{m}=\left(\frac{M_{a}-M_{f}}{M_{a}}\right) \cdot\left(\frac{d_{c}}{d_{m}}\right) \cdot 100 \\
& v_{v}=100-v_{f}-v_{m}
\end{aligned}
$$

\subsection{Análise química por Fluorescência de Raios X}

A análise de constituintes pela técnica de Fluorescência de Raios $X$ (FRX) permite obter-se dados quantitativos, semi-quantitativos e qualitativos. A realização de análise quantitativa requer padrões de concentrações conhecidas para a calibração do equipamento, o que não estava ao nosso alcance neste trabalho. Dessa forma, foi utilizada a análise semi-quantitativa por FRX. Para analisar as fibras de basalto, foram fornecidas informações de composição da 
amostra ao software do equipamento, que então realizou uma estimativa do teor dos óxidos presentes na amostra. Na figura 9 é mostrado o espectrômetro FRX utilizado, do fabricante Pananalytical modelo Axios Advanced.

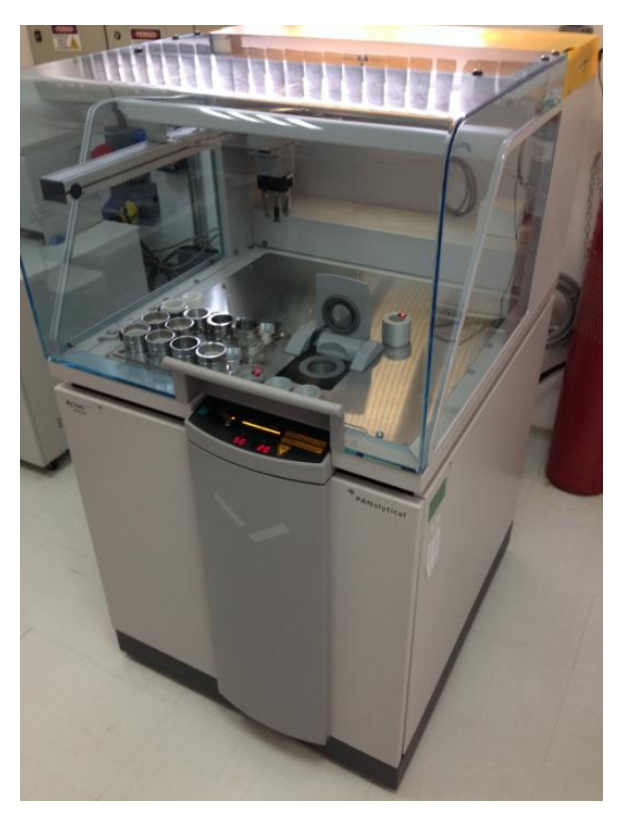

FIGURA 9 - Espectrômetro FRX.

\subsection{Ensaios mecânicos}

\subsubsection{Ensaio de tração}

Os ensaios de tração foram realizados para os corpos-de-prova cortados das placas produzidas por enrolamento filamentar, seguindo as recomendações da norma ASTM D3039/D3039M (2014).

\subsubsection{Ensaio de ruptura de anel (split disk)}

Um método de ensaio mecânico que permite determinar a resistência do compósito em estruturas cilíndricas sujeitas à pressão interna é o ensaio que mede a resistência circunferencial à tração aparente de um segmento de um cilindro em formato de anel, mais conhecido como ensaio de ruptura de anel (split disk). Este ensaio é estabelecido pela norma ASTM D2290 (2012). O aparelho utilizado neste ensaio é composto de duas seções semicirculares que são conectadas aos braços superior e inferior por pinos (FIG. 10). 
Vale destacar que este ensaio fornece um valor de resistência aparente, uma vez que um momento fletor é imposto durante o ensaio na separação entre o disco e o dispositivo de ensaio. O momento é induzido pela mudança do contorno do anel entre as duas seções do aparato semicircular durante a separação das mesmas. $O$ aparelho de ensaio é projetado para minimizar o efeito deste momento fletor. No ensaio de ruptura é possível antecipar o comportamento de uma estrutura cilíndrica em tração sob condições parecidas às que o ensaio é realizado. Pode inclusive ser usado em pesquisa e desenvolvimento, projeto, controle de qualidade e aceitação ou rejeição de peças/lotes sob especificações - expõe a norma.

A tensão aparente é obtida pela equação (5), sendo que o termo divisor 2 ocorre por existirem duas seções tracionadas.

$$
\sigma_{\mathrm{a}}=\frac{\mathrm{P}}{2 \mathrm{~A}_{\mathrm{m}}}
$$

$P$ é a carga na ruptura e $A_{m}$ é a área da seção transversal.

O ensaio de ruptura do anel foi realizado em uma máquina de ensaios universal utilizando uma velocidade da travessa de $2,5 \mathrm{~mm} / \mathrm{min}$.

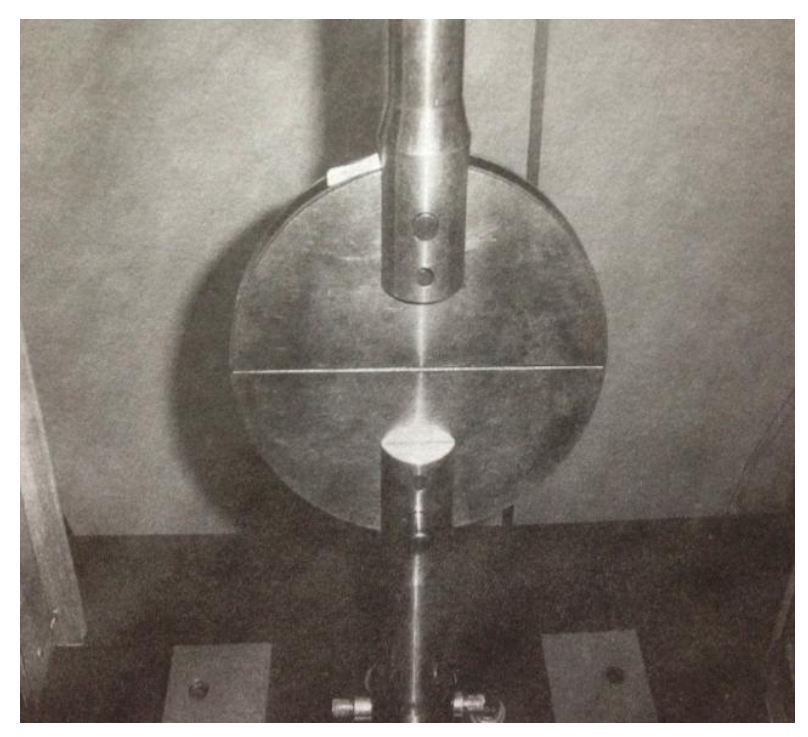

FIGURA 10 - Dispositivo de ensaio de ruptura de anel (Marinucci, 2011).

\subsubsection{Resistência ao cisalhamento interlaminar (ILSS)}

Materiais compósitos poliméricos laminados são produzidos pelo empilhamento de camadas de reforço na forma de fibras unidirecionais, tecidos 
ou pré-formas durante seu processo de fabricação. A fratura destes materiais envolve solicitação mecânica e consequentemente tensões de cisalhamento. $O$ processo conhecido como delaminação - separação entre as camadas do compósito -, verificado em análises de fratura de laminados compósitos, é um bom exemplo de como as regiões entre as lâminas são de grande interesse no que diz respeito à resistência cisalhamento interlaminar, ILSS (Interlaminar Shear Strength). Um método bastante utilizado para avaliar esta resistência é o ensaio de flexão de três pontos por viga curta, estabelecido pela norma ASTM D2344/D2344M (2013). A ideia principal deste ensaio consiste em utilizar uma distância mínima entre os apoios (quatro vezes o valor da espessura da viga), o que aumenta a proporção de tensões de cisalhamento na viga em relação às tensões de compressão e tração. A máxima tensão de cisalhamento ocorre no plano médio da espessura da viga e é dada pela equação (6):

$$
\mathrm{R}=\left(\frac{3}{4}\right) \frac{\mathrm{P}}{\mathrm{w} \cdot \mathrm{h}}
$$

em que $\mathrm{R}$ é a resistência ao cisalhamento interlaminar [MPa], $\mathrm{P}$ é a carga na ruptura [N], w é a largura [mm] e h é a espessura [mm] do corpo de prova.

Embora a tensão de cisalhamento seja dominante neste ensaio, as tensões internas são complexas (concentradas nos pontos de apoio e ponto de aplicação da carga) e uma variedade de modos de falha pode ocorrer, o que geralmente provoca o crescimento de trinca interlaminar durante o ensaio. Dessa forma o resultado da resistência encontrado pela equação 6 não fornece um valor exato da tensão de cisalhamento. Essas afirmações também justificam a tendência de início/propagação da trinca nas regiões dos planos transversais dos pontos de apoio e aplicação de carga, preferencialmente no plano médio da espessura da viga. A referida norma ainda sugere que o uso do ensaio para controle de qualidade, especificação de projeto e para comparar compósitos, já que a fratura ocorre consistentemente pelo mesmo modo.

Os corpos-de-prova utilizados no ensaio ILSS foram cortados com dimensões de $10 \times 20$ mm, como ilustra a FIG. 11. Estes foram extraídos de um anel de $10 \mathrm{~mm}$ de espessura cortado do cilindro de compósito. O critério de 
ruptura utilizado foi o momento em que ocorre o primeiro registro de queda do valor de carga no ensaio.

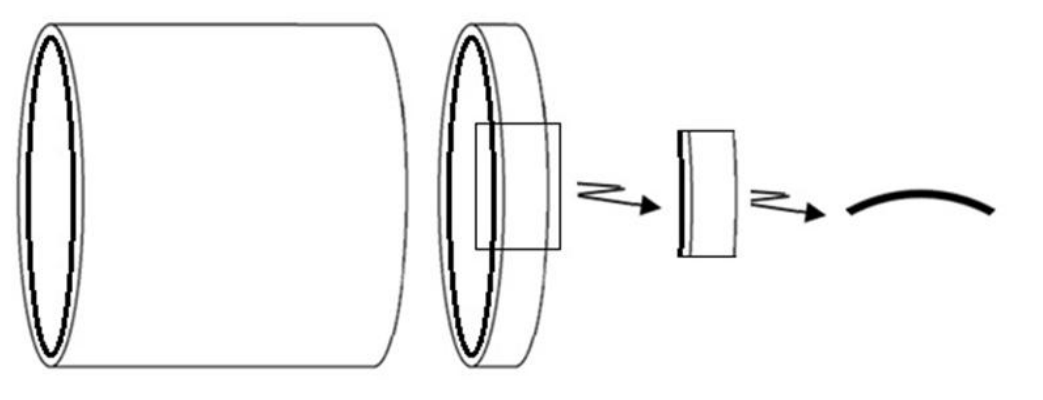

FIGURA 11 - Esquema do corte de um corpo de prova para ensaio ILSS (delimitado pelo retângulo).

Na FIG. 12 é mostrado o equipamento utilizado para o ensaio ILSS de um corpos-de-prova do compósito de FV, onde a distância utilizada entre os apoios foi de 4 vezes a espessura média dos corpos-de-prova deste compósito; para o ensaio do compósito de FB essa distância foi ajustada para 4 vezes a espessura média dos mesmos.

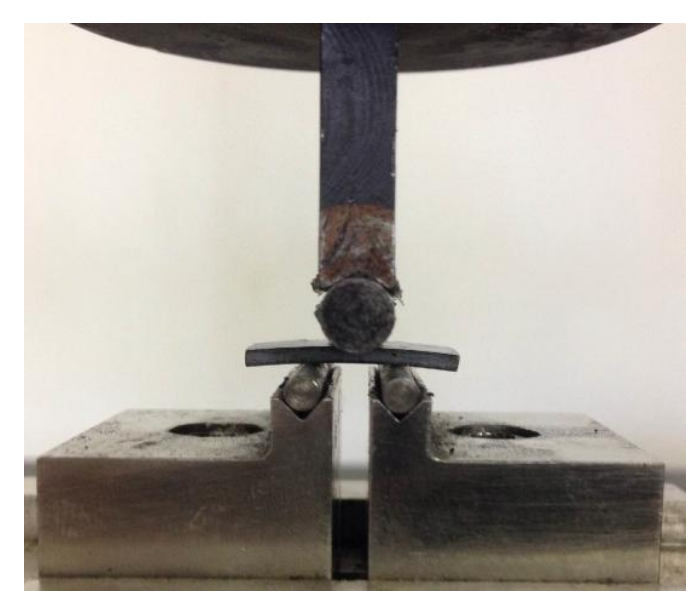

FIGURA 12 - Ensaio ILSS de corpo de prova de FV.

\subsubsection{Ensaio hidrostático}

Os cilindros de compósito de epóxi/FB e epóxi/FV foram submetidos a ensaio hidrostático onde pressão hidrostática é aplicada na superfície interna dos mesmos; este tipo de carregamento em cilindros geralmente é conhecido como 
carregamento em cilindro com extremidades abertas. O dispositivo utilizado neste ensaio foi projetado de modo a ocorrer somente o carregamento circunferencial (carregamento uniaxial), não ocorrendo carregamento longitudinal, e o cilindro permanece livre de restrições à deformação na direção longitudinal. No carregamento em cilindros com extremidades fechadas, quando submetidos à pressão interna, como ocorre em vasos de pressão, coexiste carregamento longitudinal e circunferencial (carregamento biaxial). Uma entrada situada na base do dispositivo de ensaio libera óleo bombeado para o volume delimitado por: tubo central metálico; anéis de vedação superior e inferior; e cilindro. O ensaio foi conduzido com carga monotônica (aumento constante da pressão em relação do tempo) de $55 \mathrm{kPa} / \mathrm{s}$ de pressão interna até atingir a ruptura. A unidade de pressurização utilizada possui uma bomba hidráulica com capacidade de até 100 MPa. A FIG. 13 mostra o dispositivo de ensaio hidrostático utilizado.

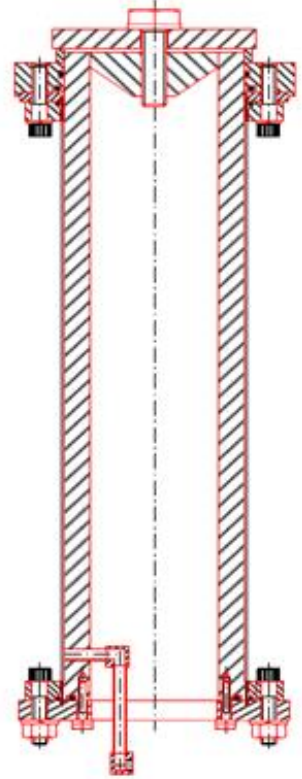

(a)

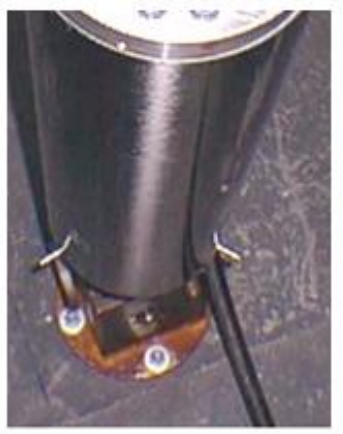

(b)

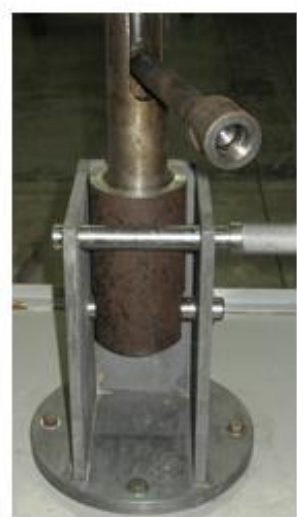

(c)

FIGURA 13 - Dispositivo de ensaio hidrostático (Marinucci, 2001: (a) desenho esquemático, (b) exemplar fabricado com fibra de basalto, (c) detalhe do bico de injeção.

\subsection{Análise da microestrutura}

A análise da microestrutura de um material compósito pode fornecer 
importantes informações sobre como será o desempenho de uma peça em serviço. Variações do volume de fibras, de vazios, variabilidade do ângulo das fibras, presença de objetos estranhos entre outros fatores podem comprometer o desempenho de um compósito (Hayes et al., 2010). Informações adicionais sobre a influência da presença de vazios nas propriedades de compósitos foram expostas na seção 4.5 deste trabalho.

\subsection{Análise térmica}

Análises térmicas pertencem a um grupo de técnicas usadas para estudar as propriedades termofísicas e cinéticas dos materiais. Seu uso em materiais poliméricos inclui o monitoramento da cura de resinas poliméricas, medição do grau de cura de um produto final, estudo da cristalinidade em termoplásticos, estudo da compatibilidade de sistemas multifásicos e identificação de transições impostas a polímeros por processamento danoso ou envelhecimento. Essas técnicas incluem a calorimetria exploratória diferencial (differential scanning calorimetry - DSC); análise termomecânica (thermomechanical analysis - TMA); análise dinâmico-mecânica (dynamic mechanical analysis - DMA); e análise dielétrica (dielectric analysis - DEA).

$D S C$ é a mais conhecida das técnicas de análise térmica. Requer pequenas amostras ( $\approx 20 \mathrm{mg}$ ), opera de -180 a $725{ }^{\circ} \mathrm{C}$ e mede o fluxo de calor associado a transições na amostra em função da temperatura (ou tempo) sob condições de atmosfera controlada. DSC tem sido usada para estudar processos (transição vítrea, capacidade térmica) e eventos cinéticos como cura e relaxações de entalpia associadas a envelhecimento e tensão. DSC é geralmente usada para medir a temperatura de transição vítrea $\left(\mathrm{T}_{\mathrm{g}}\right)$ de laminados curados, o grau de cura de um produto final, o avanço da cura em laminados, o calor de reação durante o processamento de um prepreg e a reatividade relativa de uma resina. O grau de cura é determinado tanto pelo aumento da $T_{g}$ na cura quanto pela medida do calor envolvido na reação de cura (d, 2001).

Para este trabalho, foi realizada a análise térmica de DSC para determinar a temperatura de transição vítrea $\mathrm{T}_{\mathrm{g}}$ utilizando um calorímetro exploratório diferencial Perkin Elmer modelo Pyris (FIG. 14), com atmosfera inerte nitrogênio com vazão de $20 \mathrm{~mL} \cdot \mathrm{min}^{-1}$, no intervalo de temperatura de 25 a $180{ }^{\circ} \mathrm{C}$ 
com taxa de aquecimento de $20^{\circ} \mathrm{C} \cdot \mathrm{min}^{-1}$.

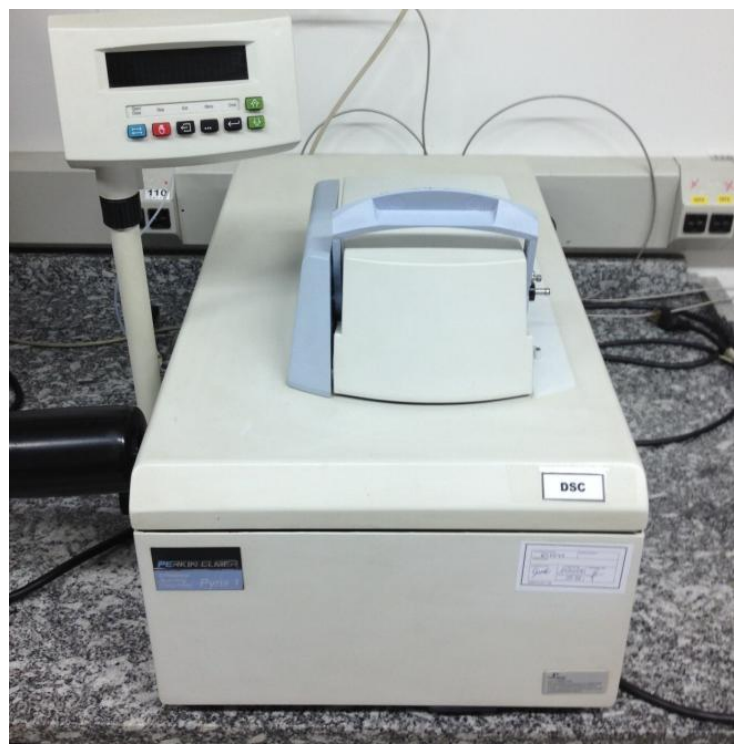

FIGURA 14 - Calorímetro exploratório diferencial.

\section{RESULTADOS E DISCUSSÃO}

\subsection{Frações volumétricas dos cilindros}

\subsubsection{Frações volumétricas por massa específica e queima da matriz}

Na TAB. 4 é mostrada a comparação entre os resultados de massa específica, frações volumétricas de fibra, matriz e vazios dos cilindros de epóxi/FB e epóxi/FV. O valor médio de massa específica obtido é praticamente igual para os dois compósitos devido aos intervalos de desvio-padrão $\left(1,98 \pm 0,02 \mathrm{~g} \cdot \mathrm{cm}^{-3}\right.$ para epóxi/FB e 1,95 $\pm 0,02$ g. $\mathrm{cm}^{-3}$ para epóxi/FV). Foram encontrados valores praticamente iguais de frações volumétricas de fibra, matriz e vazios para os dois compósitos também devido aos seus respectivos desvios-padrão.

Frações volumétricas de fibra de $55 \%$ obtidas para ambos os compósitos epóxi/FB e epóxi/FV estão abaixo dos valores encontrados para o enrolamento filamentar - a técnica permite obter-se compósitos com fração volumétrica de fibra de 60 a 75\% (Cauchois, 2009). A fração volumétrica de vazios de $3 \%$ para ambos está acima do valor esperado em um compósito estrutural (valores abaixo de $2 \%$ são esperados para essa classe de compósitos). 0 ajuste de parâmetros de produção como a tensão no filamento, distância do passo do 
enrolamento, temperatura do molde e do banho poderiam melhorar esses níveis.

Embora os cilindros não sejam reforçados com a mesma fibra, 0 processo de fabricação permitiu a obtenção de compósitos com frações volumétricas praticamente idênticas. Isso garantiu que as propriedades mecânicas dos compósitos não fossem influenciadas por uma possível fração de vazios diferente, eliminando eventuais questões como: temos diferentes propriedades devido ao tipo de fibra utilizado, ou devido a compósitos com propriedades físicas diferentes? Percebe-se com isso que o processo está bem ajustado.

TABELA 4 - Valores de massa específica, frações volumétricas de fibra e matriz e volume de vazio dos cilindros do compósito epóxi/FB e epóxi/FV.

\begin{tabular}{ccccc}
\hline Cilindro & $\begin{array}{c}\text { Massa } \\
\text { específica } \\
\mathbf{d}_{\mathbf{c}}\left(\mathbf{g . c m} \mathbf{c m}^{-3}\right)\end{array}$ & $\begin{array}{c}\text { Fibra } \\
\mathbf{V}_{\mathbf{f}}(\%)\end{array}$ & $\begin{array}{c}\text { Matriz } \\
\mathbf{V}_{\mathbf{m}}(\%)\end{array}$ & $\begin{array}{c}\text { Vazio } \\
\mathbf{V}_{\mathbf{v}}(\%)\end{array}$ \\
\hline B1 & 1,97 & 55,0 & 41,4 & 3,6 \\
B2 & 1,98 & 54,9 & 42,0 & 3,2 \\
B3 & 1,99 & 54,6 & 42,8 & 2,6 \\
B4 & 2,00 & 55,8 & 42,1 & 2,1 \\
B5 & 1,94 & 52,5 & 44,8 & 2,8 \\
B6 & 1,98 & 55,2 & 42,0 & 2,8 \\
\hline Média & 1,98 & 54,7 & 42,5 & 2,8 \\
\hline Desvio & 0,02 & 1,1 & 1,2 & 0,5 \\
\hline V1 & 1,94 & 55,1 & 41,9 & 3,0 \\
V2 & 1,97 & 56,6 & 40,7 & 2,7 \\
V3 & 1,94 & 55,0 & 41,6 & 3,4 \\
V4 & 1,94 & 54,5 & 42,6 & 2,8 \\
V5 & 1,92 & 54,6 & 41,1 & 4,3 \\
V6 & 1,97 & 56,6 & 40,6 & 2,9 \\
\hline Média & 1,95 & 55,4 & 41,4 & 3,2 \\
\hline Desvio & 0,02 & 0,9 & 0,8 & 0,6 \\
\hline
\end{tabular}




\subsection{Análise por Fluorescência de Raios X (FRX)}

Na TAB. 5 é mostrada a comparação dos resultados estimados de composição da FB obtidos por FRX com os valores da bibliografia (Artemenko, 2003). Verificou-se com isso que a maioria dos valores de teor de óxido da FB utilizada se encontra dentro do intervalo de composição dos valores da bibliografia, ou então próximos a esses valores. A não realização desta análise, ainda que semi-quantitativa, aumentaria a incerteza dos resultados obtidos neste trabalho, já que a composição química da FB varia de acordo com a jazida mineral utilizada.

TABELA 5 - Comparação entre a análise semi-quantitativa de teor de óxidos de FB e composição da FB por Artemenko (2003).

\begin{tabular}{lclc}
\hline Óxido & Fração em massa (\%) & Óxido & Fração em massa (\%) \\
\hline $\mathrm{SiO}_{2}$ & 54,3 & $\mathrm{SiO}_{2}$ & $48,8-51,0$ \\
$\mathrm{Al}_{2} \mathrm{O}_{3}$ & 14,5 & $\mathrm{Al}_{2} \mathrm{O}_{3}$ & $14,0-15,6$ \\
$\mathrm{Fe}_{2} \mathrm{O}_{3}$ & 12,7 & $\mathrm{FeO}+\mathrm{Fe}_{2} \mathrm{O}_{3}$ & $7,3-13,3$ \\
$\mathrm{CaO}$ & 9,4 & $\mathrm{CaO}$ & 10,0 \\
$\mathrm{MgO}$ & 3,6 & $\mathrm{MgO}$ & $6,2-16,0$ \\
$\mathrm{Na}_{2} \mathrm{O}$ & 2,5 & $\mathrm{Na}_{2} \mathrm{O}+\mathrm{K}_{2} \mathrm{O}$ & $1,9-2,2$ \\
$\mathrm{~K}_{2} \mathrm{O}$ & 1,4 & - & - \\
$\mathrm{TiO}_{2}$ & 1,5 & $\mathrm{TiO}_{2}$ & $0,9-1,6$ \\
$\mathrm{MnO}$ & 0,2 & $\mathrm{MnO}$ & $0,10-0,16$ \\
\hline
\end{tabular}

*Artemenko, 2003.

\subsection{Análise térmica}

A temperatura de transição vítrea $\left(T_{g}\right)$ em polímeros termofixos é caracterizada pela região da onde ocorre mudança da inclinação da curva de análise de calorimetria exploratória diferencial DSC. Na FIG. 15, que mostra as curvas de $D S C$ dos compósitos de FB e FV, é possível observar a $T_{g}$ em torno de $128^{\circ} \mathrm{C}$ para ambos os materiais. $\mathrm{O}$ valor praticamente igual de $T_{g}$ encontrado 
mostra que o processo de cura nos compósitos fabricados com as duas fibras foi bastante semelhante quanto a parâmetros que poderiam influenciar a $T_{g}$, como tempo e temperatura de cura, e umidade relativa do ar.

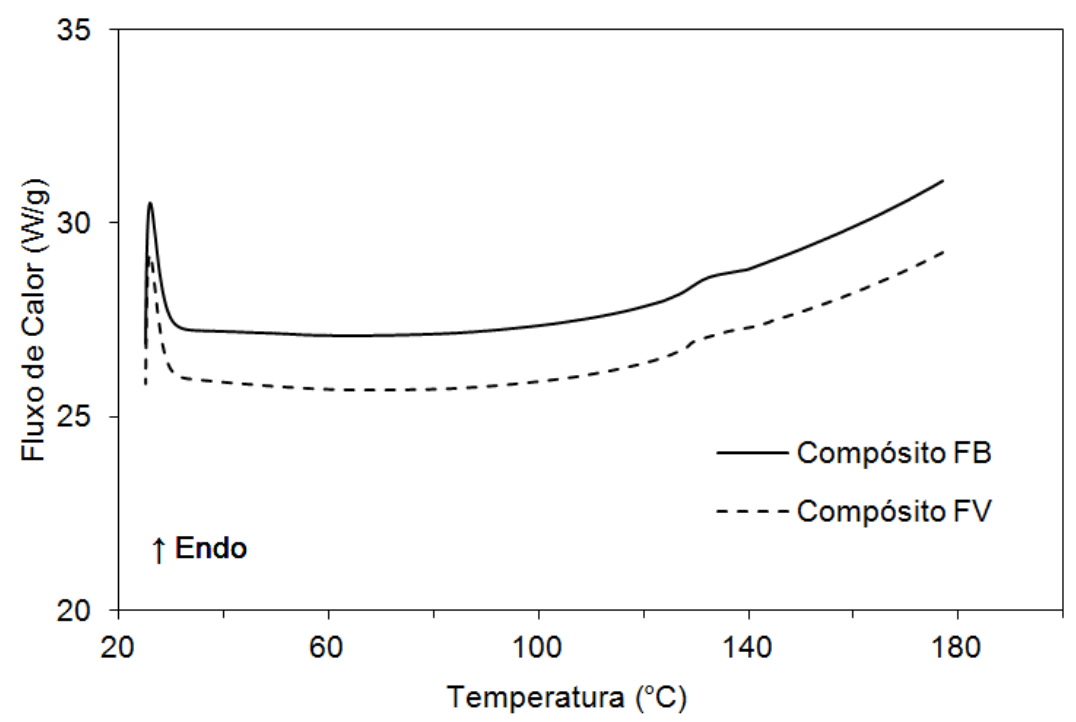

FIGURA 15 - Curvas de análise DSC dos compósitos de epóxi/FB e epóxi/FV.

\subsection{Caracterização mecânica}

\subsubsection{Propriedades mecânicas da placa de FB}

Na TAB. 6 são apresentados os resultados dos ensaios de tração dos corpos-de-prova da placa de compósito de FB na direção longitudinal $\left(0^{\circ}\right)$ e transversal $\left(90^{\circ}\right)$. Utilizaram-se cinco corpos-de-prova para cada direção do ensaio. Para obtenção do coeficiente de Poisson, as deformações nas direções longitudinal e transversal foram determinadas por meio de um extensômetro óptico. 
TABELA 6 - Propriedades experimentais das placas do compósito epóxi/FB na direção longitudinal $\left(0^{\circ}\right)$ e transversal $\left(90^{\circ}\right)$.

\begin{tabular}{lcccc}
\hline Direção & $\begin{array}{l}\text { Tensão de } \\
\text { ruptura } \\
(\mathrm{MPa})\end{array}$ & $\begin{array}{l}\text { Módulo de } \\
\text { elasticidade } \\
(\mathrm{GPa})\end{array}$ & $\begin{array}{l}\text { Coeficiente de } \\
\text { Poisson (corda } \\
\mathbf{0 . 1 0 \% - 0 . 6 0 \% )}\end{array}$ & $\begin{array}{l}\text { Deformação } \\
(\%)\end{array}$ \\
\hline $0^{\circ}$ & $1587 \pm 62$ & $49 \pm 7$ & $0,24 \pm 0,05$ & $3,30 \pm 0,21$ \\
$90^{\circ}$ & $50 \pm 1,5$ & $21 \pm 5$ & $0,53 \pm 0,18$ & $0,32 \pm 0,04$ \\
\hline
\end{tabular}

Leitão (2008) utilizou mesmo método de fabricação da placa e o mesmo tipo de matriz epóxi. A TAB. 7 mostra os valores médios da placa de compósito reforçado com $\mathrm{FB}$ e os valores médios obtidos por Leitão. A comparação destes valores permite observar que o compósito de FB exibe tensão de ruptura $15 \%$ maior na direção longitudinal $\left(0^{\circ}\right)$ e mesmo módulo de elasticidade. Na direção transversal, a tensão de ruptura do compósito de FB é $22 \%$ maior e o módulo de elasticidade $23 \%$ que o compósito de FV.

TABELA 7 - Comparação entre as propriedades mecânicas experimentais da placa dos compósitos epóxi/FB, e epóxi/FV por Leitão (2008).

\begin{tabular}{lll|ll}
\hline & \multicolumn{3}{l|}{${ }^{\star}$ Epóxi /FB } & \multicolumn{2}{l}{ *^Eóxi/FV-E } \\
\hline Direção & $0^{\circ}$ & $90^{\circ}$ & $0^{\circ}$ & $90^{\circ}$ \\
Tensão de ruptura (MPa) & $1587 \pm 62$ & $50 \pm 1,5$ & $1369 \pm 35$ & $40 \pm 3$ \\
Módulo de elasticidade (GPa) & $49 \pm 7$ & $21 \pm 5$ & $50 \pm 1$ & $17 \pm 1$ \\
\hline
\end{tabular}

* Fração volumétrica de fibra de 60-65\%.

** (Leitão, 2008), compósito com fração volumétrica de fibras de 68\%.

\subsubsection{Ensaio de ruptura de anel (split disk)}

Os ensaios de ruptura de anel foram conduzidos de acordo com a norma ASTM D2290 (2012), exceto por não ter sido realizada a redução na espessura do corpo de prova em formato de anel e pela largura do anel ser inferior ao mínimo especificado para o ensaio. Um corpo de prova em formato de anel foi cortado de cada cilindro. A TAB. 8 mostra a resistência à tração aparente de ruptura do anel, resistência à tração aparente específica e modo de falha dos compósitos epóxi/FB e epóxi/FV. 
TABELA 8 - Resistência à tração aparente e resistência à tração aparente específica de ruptura do anel dos compósitos epóxi/FB e epóxi/FV.

\begin{tabular}{ccc}
\hline $\begin{array}{c}\text { Corpo-de- } \\
\text { prova }\end{array}$ & $\begin{array}{c}\text { Resistência à tração } \\
\text { aparente (MPa) }\end{array}$ & $\begin{array}{c}\text { Resistência à tração } \\
\text { aparente específica } \\
\left(\mathbf{M P a} \cdot \mathbf{d m}^{\mathbf{3}} \cdot \mathbf{k g}^{-1} \mathbf{)}\right.\end{array}$ \\
\hline B1 & 768 & 390 \\
B2 & 714 & 360 \\
B3 & 711 & 357 \\
B4 & 705 & 353 \\
B5 & 738 & 380 \\
B6 & 727 & 367 \\
\hline Média & $\mathbf{7 2 7}$ & $\mathbf{3 6 8}$ \\
\hline Desvio & $\mathbf{2 3}$ & $\mathbf{1 4}$ \\
\hline V1 & 499 & 257 \\
V2 & 494 & 251 \\
V3 & 490 & 253 \\
V4 & 498 & 257 \\
V5 & 503 & 262 \\
V6 & 521 & 265 \\
\hline Média & $\mathbf{5 0 1}$ & 258 \\
\hline Desvio & $\mathbf{1 1}$ & 5 \\
\hline
\end{tabular}

Na FIG. 16 é apresentada a resistência à tração aparente obtida no ensaio split disk, com valor $45 \%$ maior do compósito epóxi/FB comparado ao epóxi/FV.A diferença entre massas específicas dos compósitos epóxi/FB e epóxi/FV motivou a apresentação do resultado do ensaio de split disk em valor de resistência sobre massa específica das fibras - a resistência específica, como mostra a FIG. 17. Os dados dessa figura consistem de valores médios dos corpos-de-prova com desvio padrão representado por barras verticais. Um valor $43 \%$ maior de resistência específica é encontrado no compósito de FB comparado ao de FV. 


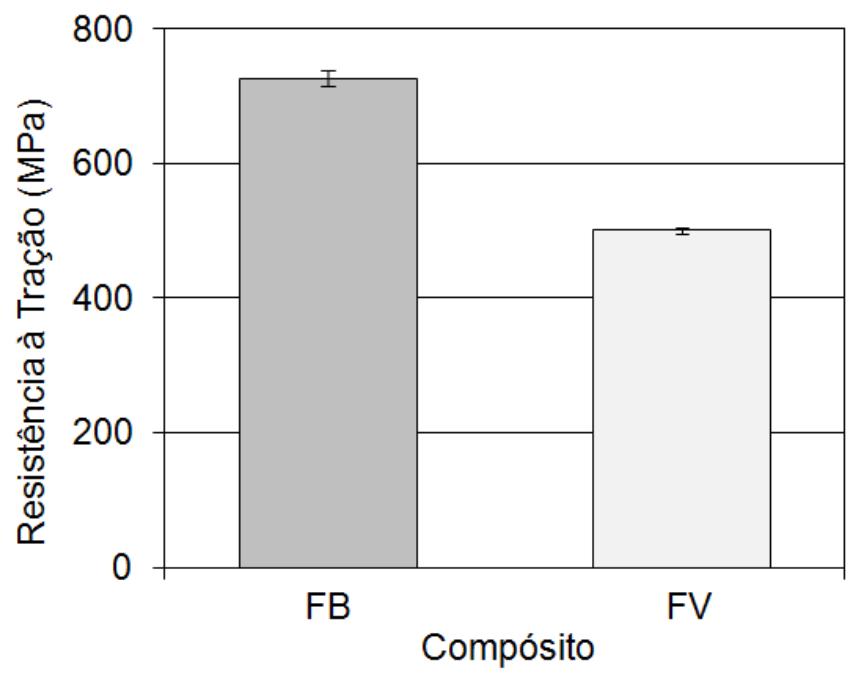

FIGURA 16 - Comparação entre a resistência à tração aparente de ruptura do anel do compósito epóxi/FB e epóxi/FB.

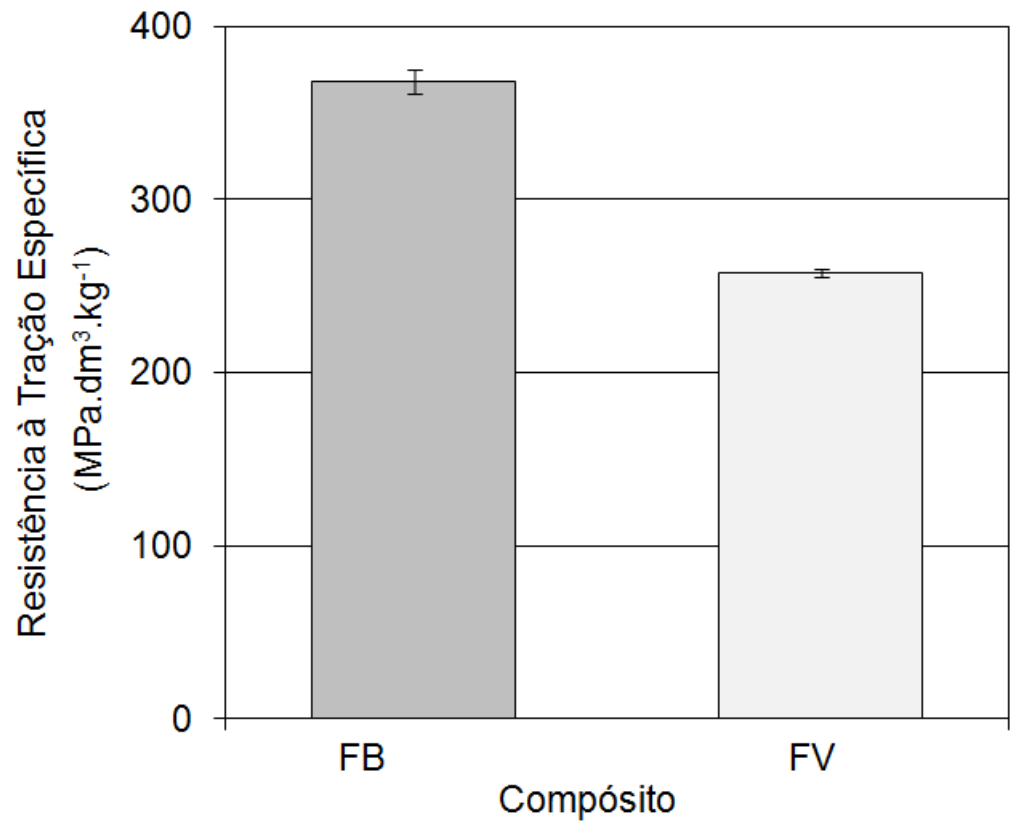

FIGURA 17 - Comparação entre a resistência à tração aparente específica de ruptura do anel do compósito epóxi/FB e epóxi/FB.

A partir de uma perspectiva de análise de falhas / análise fractográfica (Greenhalgh, 2009; Hull e Clyne, 1996), observa-se em ambos os compósitos (FIG. 18 e 19), nas camadas circunferenciais (internas e externas), descolamento entre a fibra e a matriz, fratura intralaminar e fratura das fibras. Nas camadas helicoidais (internas às circunferenciais) são observadas fraturas intralaminares ao longo da direção circunferencial. Delaminações (fratura interlaminar) são observadas na interface entre as camadas helicoidais e circunferenciais. Para o corpo de prova em formato de anel do compósito de epóxi/FV, como pode ser 
visto na FIG. 19, as camadas circunferenciais internas e externas sofreram fratura das fibras, menos descolamento e fraturas intralaminares mais extensas nas camadas circunferenciais externas do que observado nessas camadas para o compósito de epóxi/FB. Delaminações mais longas são observadas na interface entre as camadas helicoidal e circunferencial externa, em comparação com o compósito epóxi/FB.

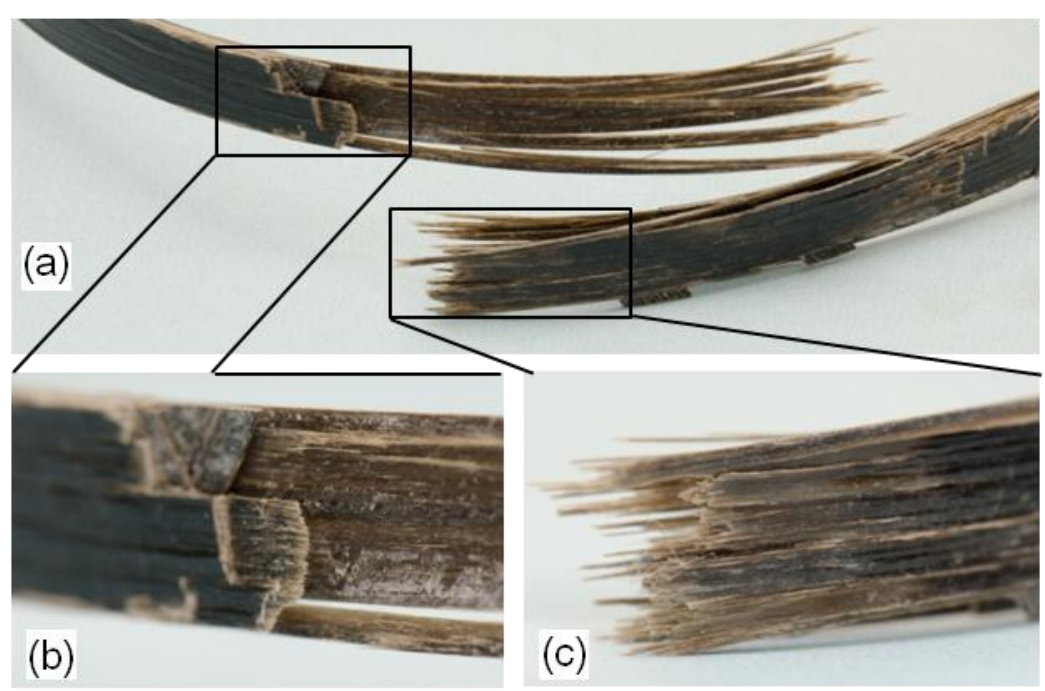

FIGURA 18 - Corpo de prova split disk do compósito epóxi/FB.

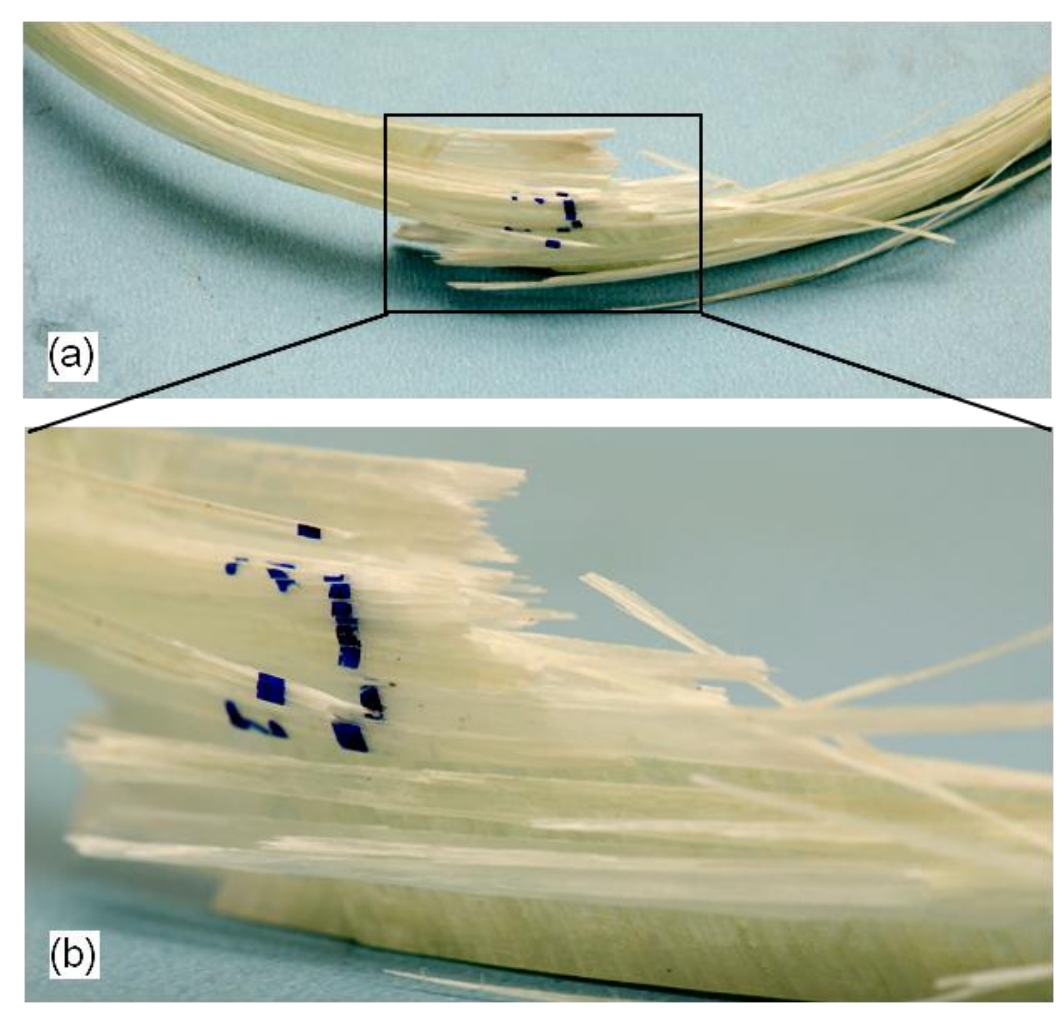

FIGURA 19 - Corpo de prova split disk do compósito epóxi/FV. 


\subsubsection{Resistência ao cisalhamento interlaminar (ILSS)}

Na FIG. 20 são mostrados os corpos-de-prova submetidos ao ensaio de viga curta, onde é possível observar (ii) trinca interlaminar na região da interface entre as camadas $+30^{\circ}$ e $-30^{\circ}$, que corresponde à região do plano médio da espessura dos mesmos. A maioria dos corpos-de-prova de ambos compósitos epóxi/FB e epóxi/FV apresentou os três modos de falha ilustrados na norma ASTM D2344/D2344M (2013): (i) falha por flexão (na região tracionada), (ii) falha por cisalhamento interlaminar (com presença de trinca no plano médio da espessura) e (iii) deformação inelástica (impressão do cilindro de carregamento sobre o corpo de prova).

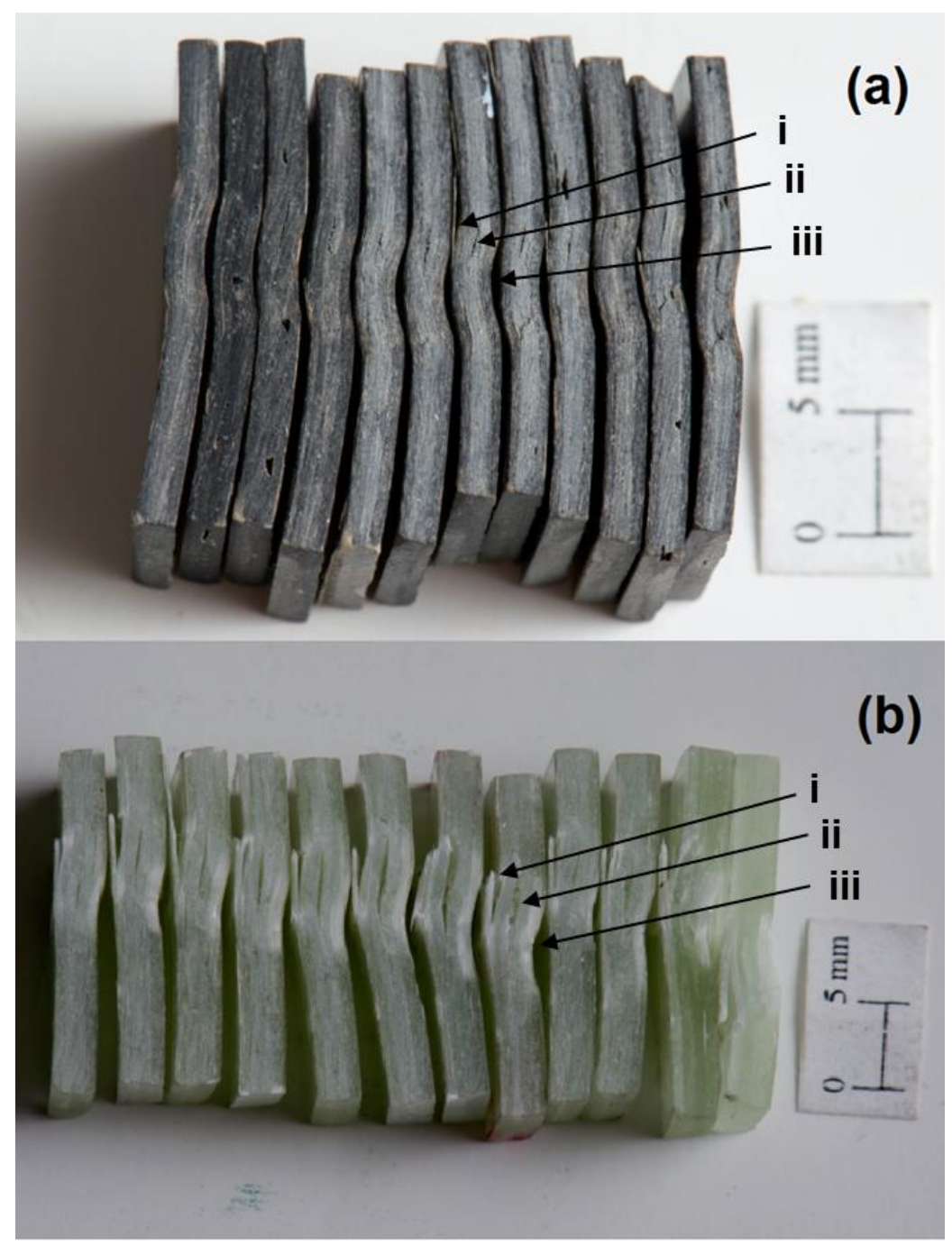

FIGURA 20 - Comparação entre o aspecto dos corpos-de-prova de compósito de epóxi/FB e epóxi/FV após ensaio de viga curta. 
Lopresto et al. (2011) realizou ensaio de viga curta seguindo a mesma norma ASTM D2344 para compósitos de fibras de basalto e de vidro-E em forma de tecido plain-weave com matriz epóxi obtendo valores de respectivamente

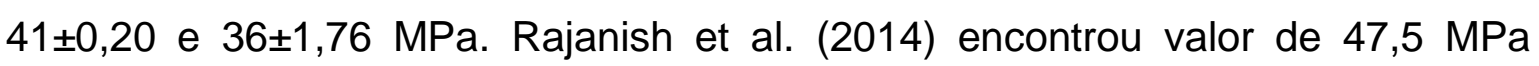
seguindo a norma mencioanada em compósito unidirecional de FV. Os valores experimentais encontrados de 70,1 MPa e 62,9 (TAB. 9) para FB e FV, respectivamente, são maiores que os valores do trabalho destes autores; como neste tipo de ensaio o valor máximo de cisalhamento interlaminar é atingido no plano médio da espessura, provavelmente a interface entre as camadas $+30^{\circ} \mathrm{e}-$ $30^{\circ}$ promove maior resistência ao cisalhamento interlaminar do que interfaces entre camadas de tecido plain-weave (para compósitos epóxi/FB e epóxi/FV) e maior do que interfaces entre camadas unidirecionais (para compósitos epóxi/FV).

TABELA 9 - Comparação entre resistência ao cisalhamento por viga (ILSS) curta para os compósitos de epóxi/FB e epóxi/FV.

\begin{tabular}{cccc}
\hline Corpo-de-prova & $\begin{array}{c}\text { Resistência ao } \\
\text { cisalhamento por } \\
\text { viga curta (MPa) }\end{array}$ & Corpo-de-prova & $\begin{array}{c}\text { Resistência ao } \\
\text { cisalhamento por } \\
\text { viga curta (MPa) }\end{array}$ \\
\hline B1 & 71,4 & V1 & 59,4 \\
B2 & 75,6 & V2 & 64,4 \\
B3 & 69,8 & V3 & 61,3 \\
B4 & 67,4 & V4 & 61,5 \\
B5 & 72,8 & V5 & 64,1 \\
B6 & 63,7 & V6 & 66,7 \\
\hline Média & $\mathbf{7 0 , 1}$ & Média & $\mathbf{6 2 , 9}$ \\
\hline Desvio padrão & $\mathbf{4 , 2 1}$ & Desvio padrão & $\mathbf{2 , 6 5}$ \\
\hline
\end{tabular}

\subsubsection{Ensaio hidrostático e análise de falha}

A TAB. 10 mostra a comparação entre os resultados de pressão de ruptura encontrados para os cilindros de compósito de epóxi/FB e epóxi/FV. O cilindro de compósito epóxi/FV apresentou pressão de ruptura média maior que o de epóxi/FB provavelmente devido à sua maior espessura média de parede $(2,58$ $\mathrm{mm}$ contra $1,58 \mathrm{~mm}$ ). Os cilindros submetidos ao ensaio hidrostático apresentaram fratura explosiva repentina. Durante a realização ensaio não foi 
observada a formação de orvalho (weeping) na superfície do cilindro, ou mesmo de jato de água anterior à ruptura, que poderiam ser um forte indicativo de falha nas camadas dos cilindros.

TABELA 10 - Comparação entre pressão de ruptura dos cilindros de compósito de epóxi/FB e epóxi/FV submetidos ao ensaio hidrostático.

\begin{tabular}{cccc}
\hline Cilindro & $\begin{array}{c}\text { Pressão de } \\
\text { ruptura (MPa) }\end{array}$ & Cilindro & $\begin{array}{c}\text { Pressão de } \\
\text { ruptura (MPa) }\end{array}$ \\
\hline B1 & 12,3 & V1 & 14,7 \\
B2 & 14,2 & V2 & 13,2 \\
B4 & 13,7 & V4 & 14,5 \\
\hline Média & 13,4 & Média & 14,2 \\
\hline Desvio padrão & 1,0 & Desvio padrão & 0,8 \\
\hline
\end{tabular}

A tensão de membrana em um vaso de pressão cilíndrico de paredes finas é dado pela equação (7):

$$
\sigma=\frac{\operatorname{Pr}}{t}
$$

na qual "P" é a pressão interna, "r" é o raio do cilindro e "t" é a espessura da parede.

Utilizando o valor médio de pressão de ruptura do cilindro epóxi/FB, da TAB. 10, e seu valor médio de espessura da parede dos cilindros, obtemos $\sigma$ de $(8,5 \pm 0,6)$ r. Fazendo o mesmo procedimento com a pressão de ruptura do cilindro de epóxi/FV, da TAB. 10 e espessura média de parede, obtemos $\sigma$ de $(5,5+0,3)$ r. Portanto, embora a tensão de ruptura do cilindro de epóxi/FV tenha sido $6 \%$ maior que no cilindro de epóxi/FB, a tensão de membrana média na ruptura dos cilindros de epóxi/FB foi 55\% maior que a dos cilindros de epóxi/FV.

Para ambos os materiais (FIG. 21 a 24) é possível verificar um padrão de ruptura semelhante, localizado em uma faixa de extensão ao longo da altura do cilindro, onde é observada a ruptura das fibras (fratura translaminar) e o descolamento das camadas circunferenciais mais externas, resultado de extensas delaminações (fratura interlaminar) na interface entre esta e a camada helicoidal.

O descolamento das camadas circunferenciais deixa exposta a camada 
helicoidal, que apresenta fraturas translaminares sem ocorrência de ruptura das fibras. No caso do compósito epóxi/FB (FIG. 21 e 22), as camadas circunferenciais mais externas foram completamente descoladas da camada helicoidal na região da fratura; para o compósito epóxi/FV (FIG. 23 e 24), essas camadas foram parcialmente descoladas.

O aspecto das fraturas encontrado nos cilindros estudados poderia ser denominado gaiola de pássaro (birdcaging). Souza et al. 2012 e Bectarte and Coutarel 2004 utilizaram o termo birdcaging para denominar a excessiva expansão radial, em tubos flexíveis, da armadura de tração dos fios de aço deste material compósito - este tipo de tubo é constituído de várias camadas de aço e de polímero e tem sido utilizado para transferir petróleo e gás de poços offshore para instalações de produção flutuantes.
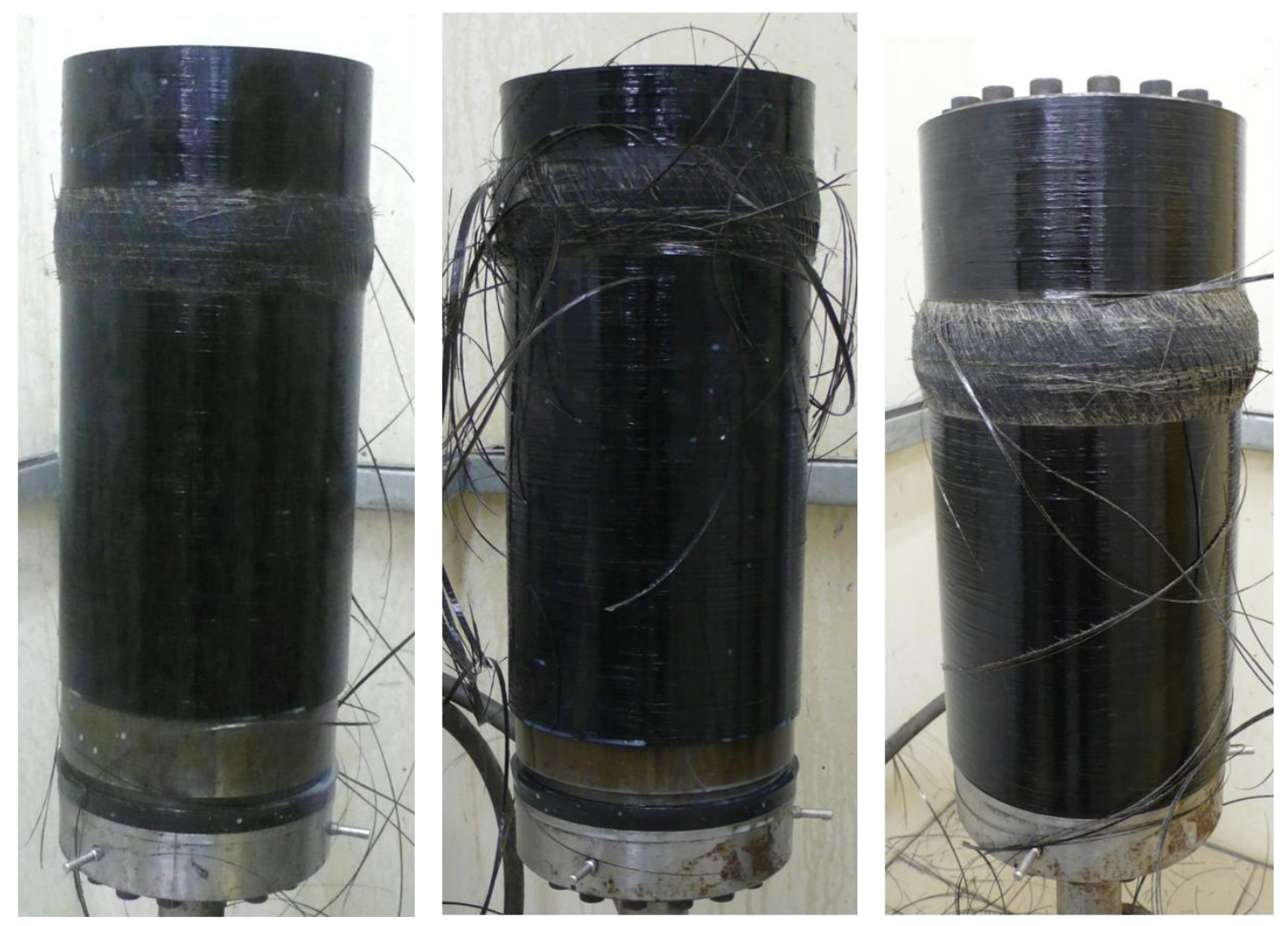

FIGURA 21 - Aspecto dos cilindros de compósito epóxi/FB após ensaio hidrostático. 

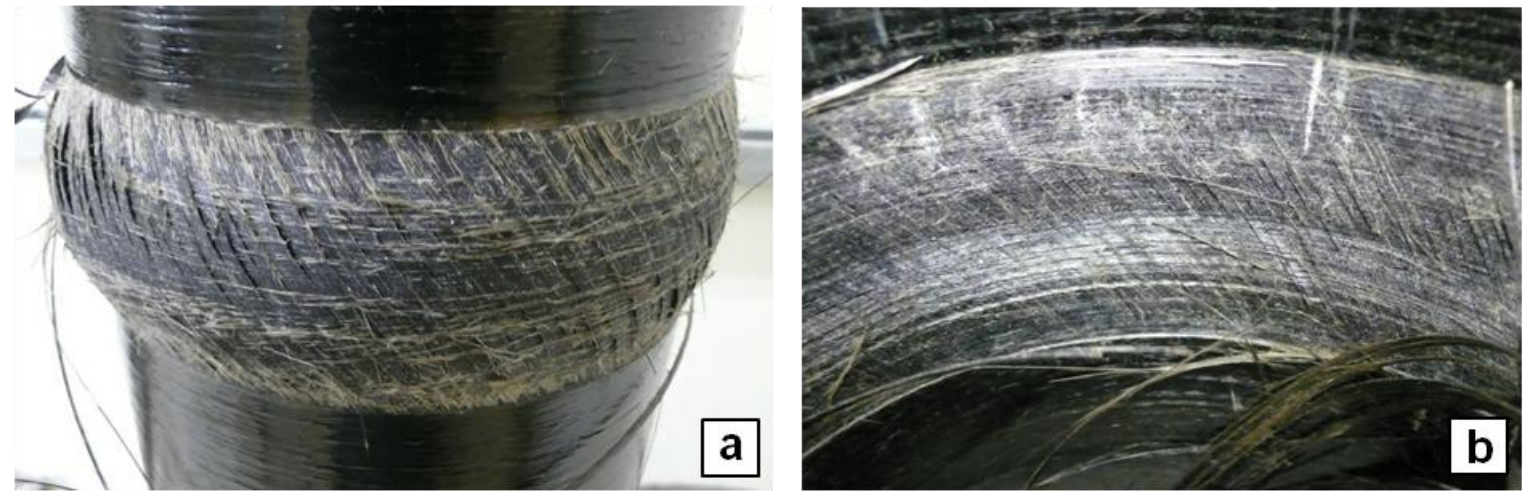

FIGURA 22 - Região de fratura do cilindro de compósito epóxi/FB após ensaio hidrostático mostrando (a) lado externo e (b) lado interno.
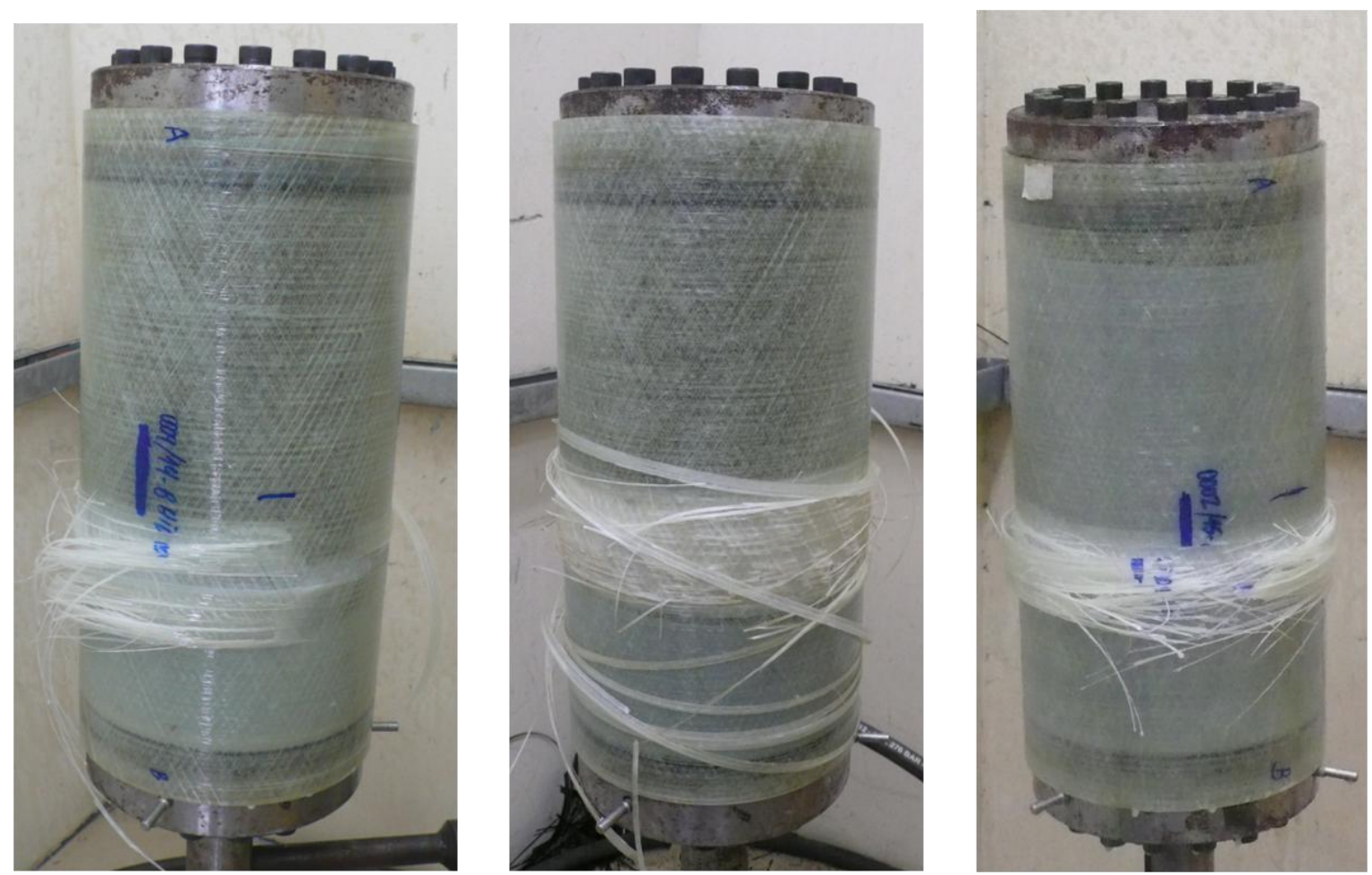

FIGURA 23 - Aspecto dos cilindros de compósito epóxi/FV após ensaio hidrostático. 

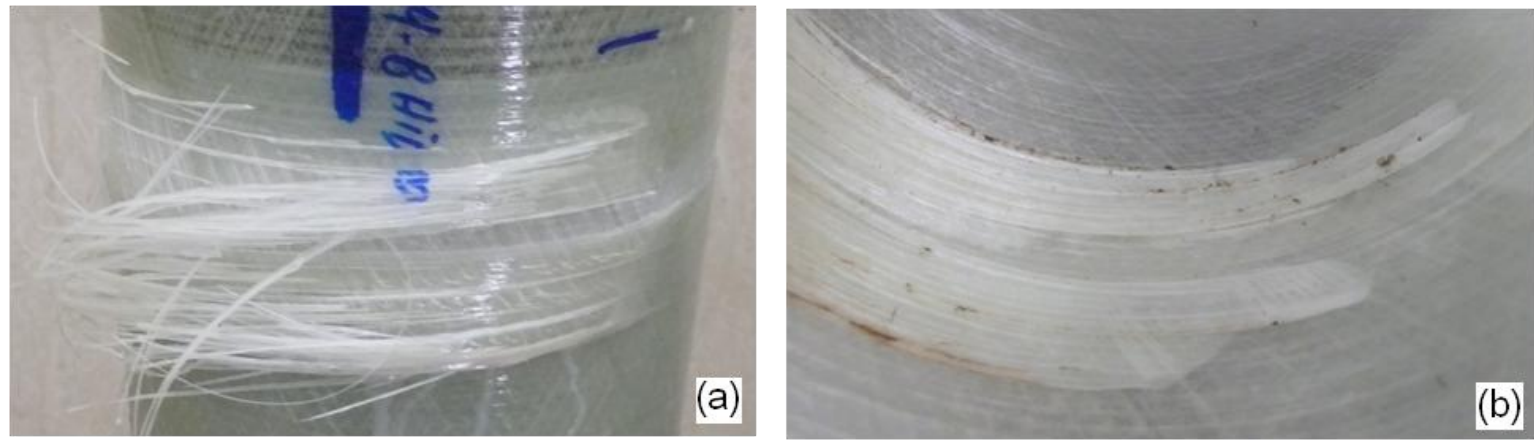

FIGURA 24 - Região de fratura do cilindro de compósito epóxi/FV após ensaio hidrostático mostrando (a) lado externo e (b) lado interno.

Uma forma de prever a maneira pela qual o processo de fratura ocorre em um compósito laminado consiste em avaliar as tensões envolvidas no carregamento para cada lâmina e adotar um critério de falha apropriado. Hull e Clyne (1996) realizaram esta análise para um laminado cross-ply (em que as fibras estão dispostas em ângulo de $90^{\circ}$ entre as camadas, em relação à direção principal) de compósito epóxi/FV com fração volumétrica de fibras de $50 \%$ com carregamento uniaxial na direção $0^{\circ}$ demonstrando que as lâminas com fibras transversais à direção do carregamento falham primeiro por apresentarem deformação de ruptura muito menor que as lâminas com fibras na longitudinal. É possível afirmar que as camadas helicoidais $\pm 30^{\circ}$ dos cilindros submetidos ao ensaio hidrostático também falhariam primeiro, uma vez que há igual situação de carregamento no laminado (uniaxial, na direção circunferencial - na direção longitudinal das fibras), e que as camadas helicoidais $\pm 30^{\circ}$ também apresentam deformação de ruptura muito menor.

Embora esta propriedade não tenha sido medida neste trabalho, Leitão (2008) verificou que laminados compósitos de FV unidirecional e angle-ply $\pm 60^{\circ}$ possuem deformação de ruptura de $4,0 \%$ e $0,4 \%$, respectivamente. O laminado angle-ply $\pm 60^{\circ}$ tem condição de carregamento equivalente às camadas helicoidais dos cilindros avaliados neste trabalho, porque 0 ângulo $\pm 30^{\circ}$ identificador da configuração de bobinagem é relativo à deposição ao longo do eixo do molde, mas o carregamento do ensaio hidrostático utilizado neste trabalho ocorre circunferencialmente, $\pm 60^{\circ}$ em relação às fibras.

A fratura encontrada em trabalho que também utilizou enrolamento 
filamentar e configuração de enrolamento semelhante, mas utilizando fibra de carbono como reforço (Carvalho, 2006), apresentava longas trincas longitudinais e na direção helicoidal, com visível ruptura da parede do laminado ao longo da maior parte da extensão do cilindro. No presente trabalho este aspecto de fratura não foi observado, sendo que as características principais da fratura dos cilindros de compósito epóxi/FB e epóxi/FV foram o rompimento das fibras da camada circunferencial externa e trincas intralaminares nas camadas helicoidais, ocorrendo em uma faixa do cilindro. Dessa forma, cilindros fabricados pelo procedimento e com os materiais utilizados neste trabalho, sob carregamento hidrostático circunferencial, exibem menor dano na ruptura do que cilindros reforçados com fibra de carbono, o que poderia permitir reparo do componente rompido e melhor atender a requisitos de segurança em um projeto que utilize um cilindro em material compósito com características semelhantes ao deste trabalho.

\subsubsection{Mecanismo de fratura proposto}

Nas FIG. 22 e 24 são mostradas em detalhe as regiões de fratura dos cilindros epóxi/FB e epóxi/FV, respectivamente, onde é possível verificar que as camadas helicoidais $\pm 30^{\circ}$ sofreram fraturas intralaminares. Um cilindro com esta região em destaque é mostrado na ilustração esquemática da FIG. 25(a), e uma vista do corte transversal do cilindro na FIG. 25(b). No item 5.3.4 foi explicado que as mesmas possuem menor deformação de ruptura em relação às camadas circunferenciais, sofrendo fratura primeiro que estas e assim Ihes transferindo carga (FIG. 25(c)). A ruptura das camadas helicoidais da forma que foi observada, em uma faixa de altura do cilindro, aumenta o carregamento nas camadas circunferenciais nesta região. Isso torna maior a deformação das camadas circunferenciais desta faixa em relação às camadas circunferenciais do restante do cilindro, promovendo a fratura translaminar das mesmas nesta região (FIG. 25(d)) e o vazamento do óleo comprimido, com fratura das fibras e descolamento dessas camadas, aspectos que foram observados nos cilindros fraturados. 
(a)

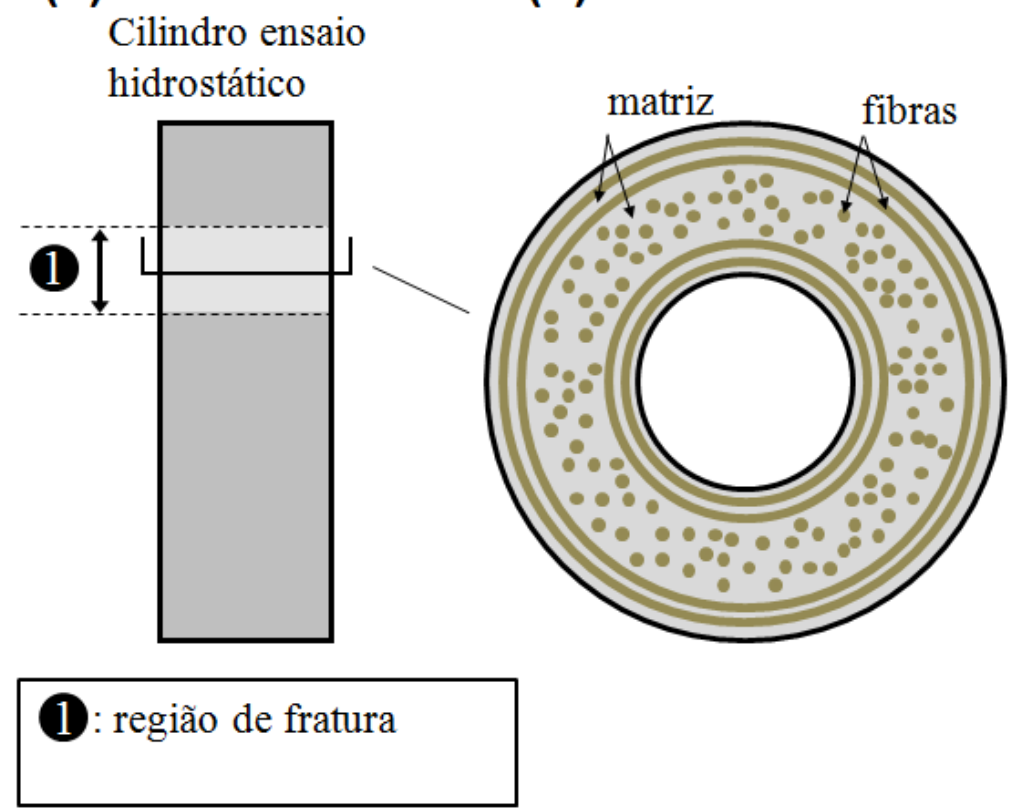

(c)

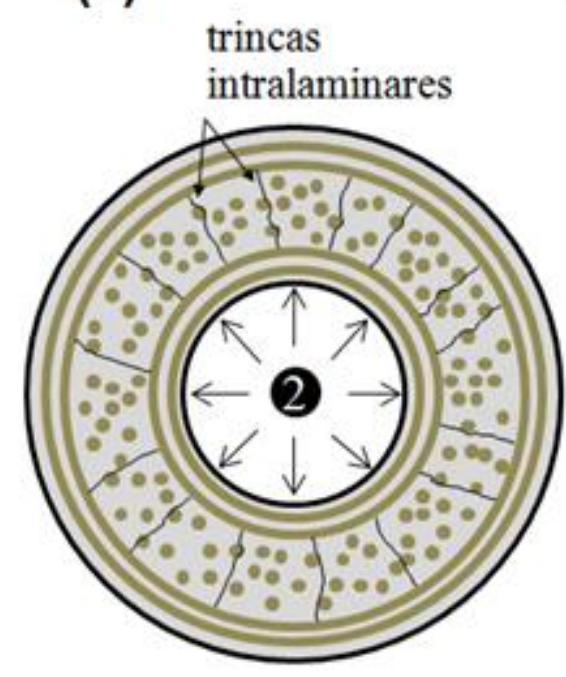

Fratura da camada helicoidal

2: região pressurizada (d) fraturas translaminares

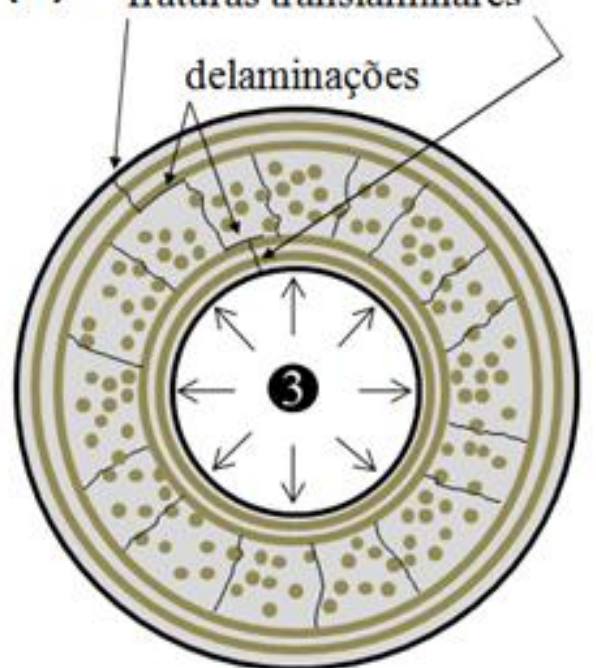

Fratura da camada circunferencial

(3): aumento da pressão aumento do diâmetro

FIGURA 25 - Ilustração esquemática da fratura do cilindro durante ensaio hidrostático na (a) região de fatura, com representação em (b) corte através da região da região de fratura, mostrando a (c) fratura da camada helicoidal e da (d) da camada circunferencial. 


\subsection{Microscopia óptica dos cilindros}

Nas FIG. 26 e 27 são mostradas micrografias da seção longitudinal de uma parede dos cilindros de compósito de epóxi/FB e de epóxi/FV, respectivamente. A matriz cor cinza escuro envolve os filamentos cinza mais claro. Os vazios, regiões esféricas de cor preta, apresentaram tamanho que varia até no máximo $200 \mu \mathrm{m}$ em ambos os compósitos. As camadas estão identificadas por seus ângulos de deposição e a separação entre elas é indicada por um traço vertical pontilhado. Não é possível distinguir separação entre as duas camadas circunferenciais adjacentes (identificados por $90^{\circ}$ ). As imagens correspondem aos cilindros na posição vertical, e as primeiras duas camadas circunferenciais depositadas sobre o molde durante a fabricação estão localizadas à esquerda (fibras com aspecto circular), seguidas de duas camadas helicoidais (fibras com aspecto oval, já que sofreram corte não perpendicular) e das últimas duas camadas circunferenciais (fibras com aspecto circular), totalizando $\left[90^{\circ}{ }_{2} /\right.$ $30 \%+30 \% / 90_{2}^{\circ}{ }_{2}$ T. Observa-se um menor empacotamento das fibras nas camadas helicoidais - regiões ricas em resina são mais visíveis nessas camadas. Isto possivelmente conferiu maior espessura média a essas; é possível observar que essas duas camadas possuem em torno do dobro da espessura da parede do cilindro e, portanto, possuem um valor de espessura média

com aproximadamente 0 dobro do valor da espessura média das camadas circunferenciais.

A análise de imagem da seção de um material compósito também pode ser utilizada na determinação de suas frações volumétricas (Cohen et al., 2001; Paciornik et al., 2010). Foram determinadas a fração em área de vazios para as duas micrografias (FIG. 26 e 27) das seções longitudinais do compósito, utilizando o software para tratamento de imagens ImageJ. O software possui uma funcionalidade que permite demarcar as regiões mais escuras da imagem, referentes aos vazios, e que calcula sua fração relativa ao restante da imagem.

No caso do compósito epóxi/FB, foi encontrada uma fração em área de vazios de $1,1 \%$, e no compósito de $\mathrm{FV}, 0,7 \%$, valores em torno de um terço do valor médio de fração volumétrica de vazios de aproximadamente $3 \%$ encontrados para ambos os compósitos (na seção 5.1.1). Essa diferença provavelmente se deve à menor representatividade do método de análise de 
imagem utilizado, onde apenas uma imagem ampliada da superfície do compósito foi analisada, enquanto que no método de queima da matriz o volume das amostras do compósito é analisado.

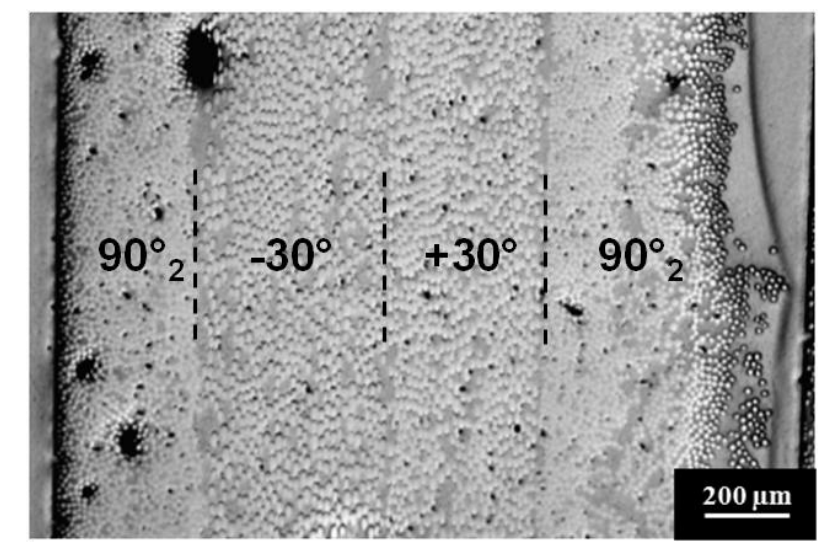

FIGURA 26 - Micrografia da seção longitudinal do cilindro de compósito epóxi/FB.

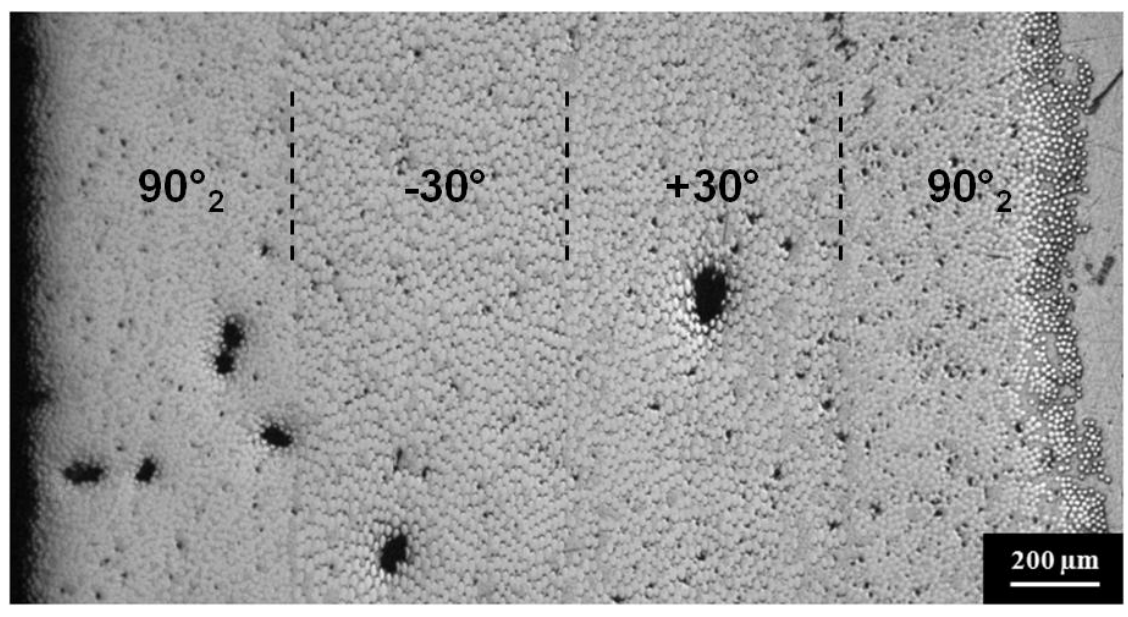

FIGURA 27 - Micrografia da seção longitudinal do cilindro de compósito epóxi/FV.

\subsection{Microscopia eletrônica de varredura (MEV) dos cilindros}

As imagens desta seção foram obtidas utilizando elétrons secundários de um microscópio eletrônico de varredura. A FIG. 28 mostra a MEV das FB sem impregnação de resina epóxi, evidenciando aspecto liso e arredondado das mesmas. 


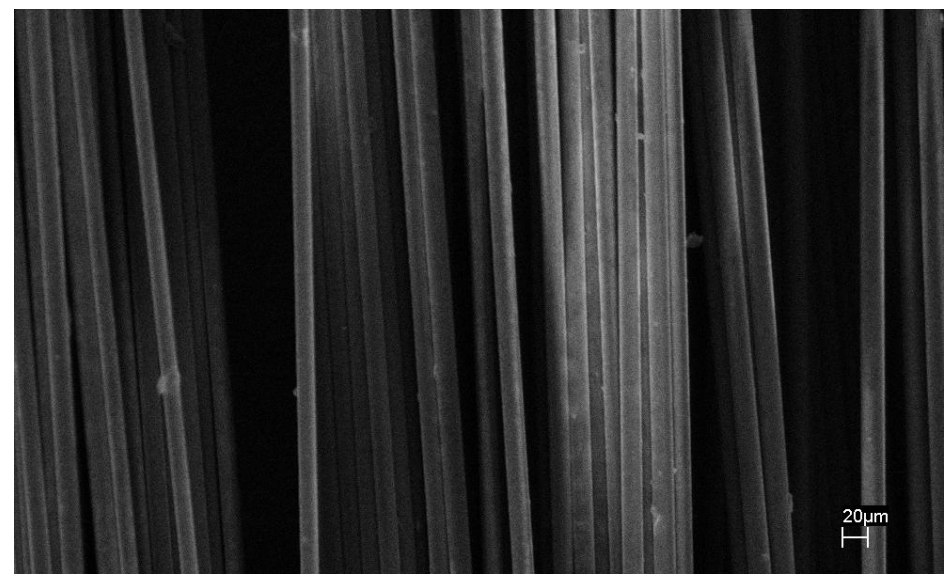

FIGURA 28 - MEV das FB sem impregnação de resina epóxi.

Durante o ensaio hidrostático houve o descolamento das camadas circunferenciais mais externas dos cilindros. A FIG. 29 mostra uma destas camadas que se descolou do cilindro (que fazia interface com camada helicoidal), mostrando uma região de fratura das fibras (fratura translaminar). Observa-se pouco descolamento das fibras em relação à matriz nesta região, o que é uma evidencia de boa resistência interfacial relativa entre a fibra e a matriz.

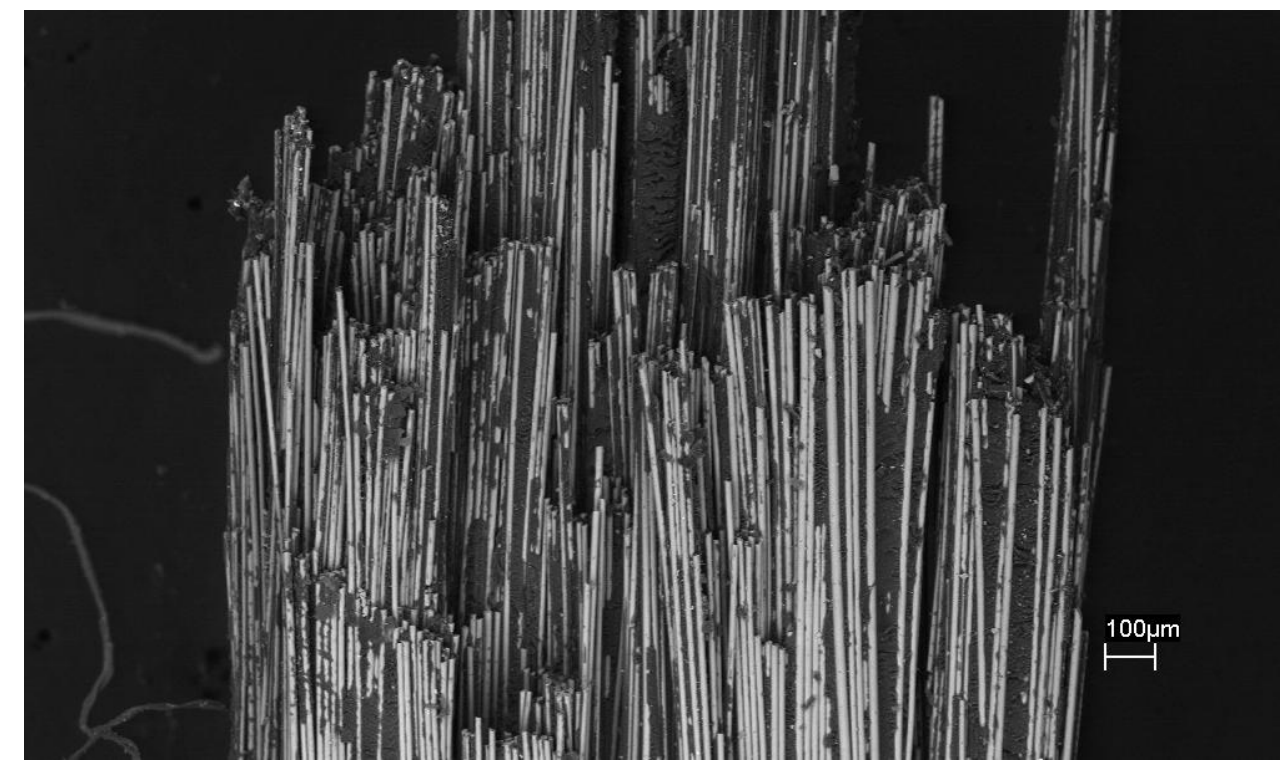

FIGURA 29-MEV da fratura translaminar da camada circunferencial do compósito epóxi/FB.

A principal característica fractográfica em superfícies de fratura por cisalhamento modo II são as cúspides. A direção de inclinação das cúspides fornece uma indicação da direção do cisalhamento de duas superfícies 
correspondentes; por exemplo, se as cúspides de uma microscopia de fratura estão inclinadas para a esquerda, isto é um indicativo de que a superfície de fratura correspondente se moveu da esquerda para a direita. Extensa bibliografia relata essa característica, como descrito por Greenhalgh, 2009.

$\mathrm{Na}$ FIG. 30 é mostrado a MEV da superfície interna de uma camada circunferencial mais externa de um cilindro epóxi/FB, que se descolou durante 0 ensaio hidrostático. A seta indica a direção circunferencial de $90^{\circ}$, que é a direção do carregamento do ensaio hidrostático e das fibras desta camada.

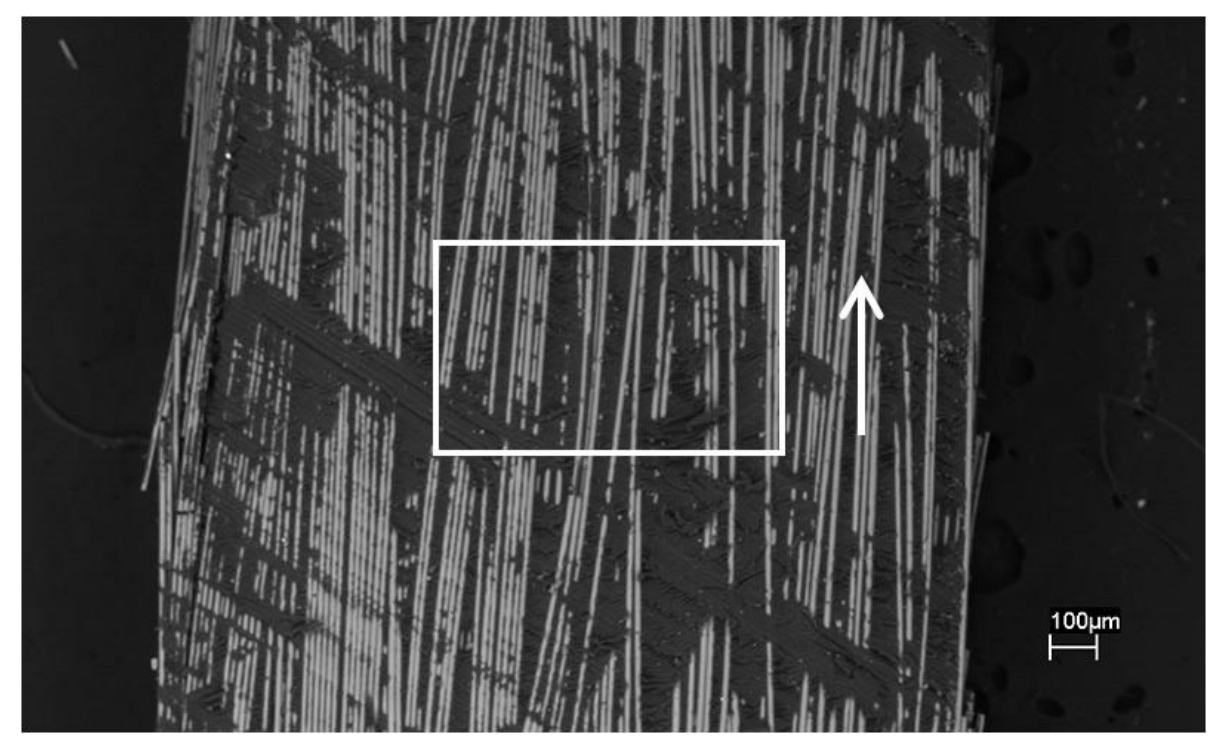

FIGURA 30 - MEV da camada circunferencial do compósito epóxi/FB.

A FIG. 31, mostra em detalhe região do retângulo da FIG. 30. Apesar do carregamento no ensaio ocorrer na direção circunferencial (na direção das fibras da imagem, com ângulo de 90), a inclinação das cúspides em ângulo de aproximadamente $30^{\circ}$ indica a ocorrência de cisalhamento local neste sentido, com movimento desta superfície neste sentido e da superfície de fratura correspondente no sentido contrário. No canto inferior esquerdo da figura também é possível observar impressões das fibras da camada subsequente do cilindro (superfície de fratura correspondente), a camada helicoidal mais externa, que aparece com orientação de $-30^{\circ}$. 


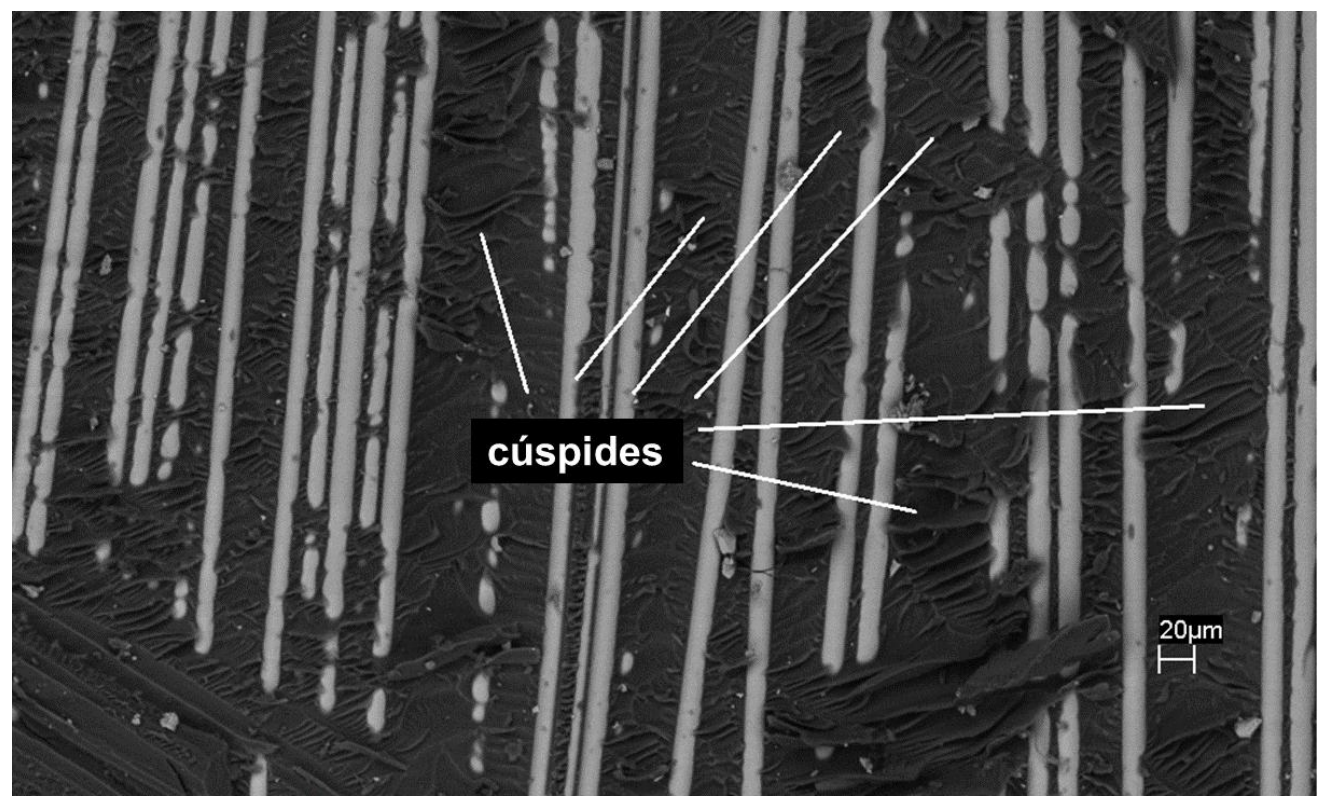

FIGURA 31 - MEV em detalhe da camada circunferencial do compósito epóxi/FB (demarcado pelo retângulo na FIG. 30).

\section{CONCLUSÕES}

Os compósitos epóxi/FB superaram ou igualam os epóxi/FV nas comparações entre resultados dos valores das propriedades mecânicas avaliadas, nas seguintes porcentagens: resistência à tração longitudinal $\left(0^{\circ}\right)$, em $15 \%$ e mesmo módulo de elasticidade; resistência à tração transversal $\left(90^{\circ}\right)$, em $22 \%$ e $23 \%$ em módulo de elasticidade; resistência à tração aparente de ruptura de anel em $45 \%$ e $43 \%$ em resistência específica; resistência ao cisalhamento por viga curta, em 11\%; resistência/tensão de membrana de ruptura no ensaio hidrostático, em $55 \%$.

O tipo de fibra utilizada como reforço (FB ou FV) na fabricação dos compósitos em forma de cilindro pela técnica de enrolamento filamentar não teve influência nos valores das frações volumétricas (de fibra, matriz e vazios) e de temperatura de transição vítrea $\left(T_{g}\right)$, já que tais propriedades encontradas são praticamente iguais em ambos compósitos.

Os valores médios de fração volumétrica de fibra (55\%) e de vazios (3\%) obtidos para ambos os compósitos epóxi/FB e epóxi/FV poderiam ser alterados com ajuste de parâmetros de produção. Com isso poderia ser obtido valores adequados a aplicações estruturais, no caso da fração de vazios.

Provavelmente a interface entre as camadas $+30^{\circ}$ e $-30^{\circ}$ promove 
maior resistência ao cisalhamento interlaminar do que interfaces entre camadas de tecido plain-weave (para compósitos epóxi/FB e epóxi/FV) e maior do que interfaces entre camadas unidirecionais (para compósitos epóxi/FV).

Os Cilindros fabricados neste trabalho, sob carregamento hidrostático circunferencial, exibem menor dano na ruptura do que cilindros reforçados com fibra de carbono, o que poderia permitir reparo do componente rompido e melhor atender a requisitos de segurança na utilização dos mesmos.

\section{TRABALHOS FUTUROS}

- Ensaio hidrostático de cilindros de compósito de FB e FV utilizando extensiômetros strain gages, permitindo traçar curvas de tensão versus deformação nas direções circunferencial e longitudinal; obtenção de valor médio da pressão de ruptura.

- Análise de tensões utilizando software de elementos finitos.

- Análise de fratura com utilização de câmera de alta velocidade para melhor entendimento do mecanismo de fratura presente no ensaio hidrostático.

\section{REFERÊNCIAS BIBLIOGRÁFICAS}

ASM INTERNATIONAL, Composites. ASM Handbook, v. 21, ASM International, 2001, p. 2236.

ASM INTERNATIONAL. Void Analysis of Composite Materials. Optical Microscopy of Fiber-Reinforced Composites. ASM International, 2010, p.147-158.

BASFIBER. Advanced basalt fibers for high-performance filament winding. Disponível em: <www.basfiber.com/publikations>. Acesso em: $20 \mathrm{de}$ jan. de 2014.

BASFIBER. Kammeny Vek, ficha técnica. Disponível em: <www.basfiber.com>. Acesso em: 20 de jan. de 2014.

ARTEMENKO, S. E. Polymer composite materials made from carbon, basalt and glass fibres. Structure and properties. Fibre Chemistry, v.35, 끄.3, 2003.

BECTARTE, F.; COUTAREL, A. Instability of tensile armour layers of flexible pipes under external pressure. Anais do 23 OMAE, Vancouver, Canada, 2004.

CALLISTER JÚNIOR, W. D. Ciência e engenharia de materiais: uma 
introdução. 5.ed. LTC, Rio de Janeiro, 2000.

CARVALHO, O. Influência da configuração de bobinagem no comportamento mecânico de cilindros de compósito polimérico. Dissertação de mestrado, São Paulo, 2006.

CAUCHOIS, J. P. Processos em compósitos. In: ABMACO. Compósitos I, materiais, processos, aplicações, desempenhos e tendências. Sem editor, p.450-452, 2009.

CHAWLA, K.K. Composite Materials, Science and Engineering. New York, $2^{\circ}$ ed., Springer, 2001.

CHIKHRADZE, N. M.; JAPARIDZE, L. A.; ABASHIDZE, G. S. Properties of Basalt Plastics and of Composites Reinforced by Hybrid Fibers in Operating Conditions. Composites and Their Applications, Ning Hu, Agosto de 2012.

COHEN, D. Influence of filament winding parameters on composite vessel quality and strength. Composites Part A, v.28A, p.1035-1037, 1997.

COHEN, D.; TOOMBES, Y. T.; JOHNSON, A. K.; HANSEN, M. F. Pressurized ring test for composite pressure vessel hoop strength and stiffness evaluation. Journal of Composites Technology \& Research. v.17, №4, p.331-340, 1995.

COHEN, D.; MANTELL, S. C.; ZHAO, L. The effect of fiber volume fraction on filament wound composite pressure vessel strength. Composites B, v.32, p.413-429, 2001.

COLOMBO, C.; VERGANI, L.; BURMAN, M. Static and fatigue characterization of new basalt fibre reinforced composites. Composite Structures, v.94, p. 1165-1174, 2012.

COLOMBO, C.; VERGANI, L.; BURMAN, M. Static and fatigue characterization of new basalt fibre reinforced composites. Composite Structures, v.94, p. 1165-1174, 2012. In: BURGOYNE, C.J.; TARANU, N.; PILAKOUTAS, K.; SERBESCU, A.; TAMUZS, V.; WEBER, A. FRP reinforcement in RC structures. FIB technical report. Stuttgart: Sprint Digital, Druck Editor, 2007.

FAZIO, P. Basalt fibra: from earth an ancient material for innovative and modern application. Energia, Ambiente e Innovazione, 3/2011.

FIORE, V.; SCALICI, T.; Di BELLA, G; VALENZA, A. A review on basalt fibre and its composites. Composites Part B, v.74, p.74-94, 2015.

GREENHALGH, E. S. Failure analysis and fractography of polymer composites. p. 37, 226, 227.CRC Press LLC, Boca Raton, 2009.

HAO, L.C.; YU, W.D. Evaluation of thermal protective performance of basalt fibre nonwoven fabrics. Journal of Thermal Analysis and Calorimetry, v.100, p.551-555, 2010. 
HAYES, B. S.; LUTHER, M. G. Optical Microscopy of Fiber-Reinforced Composites, p. 137. Ohio, ASM International, 2010.

HULL, D.; CLYNE, T. W. An introduction to composite materials. $2^{a}$ ed, Cambridge University Press, New York, 1996.

IGAMI, M.P.Z.; ZARPELON, L.M.C. (Org). Guia para a elaboração de dissertações e teses: preparado para orientação dos alunos de Pósgraduação do IPEN. São Paulo: IPEN, Divisão de Informação e Documentação Científicas, 2002.

LAFFAN, M. J.; PINHO, S. T.; ROBINSON, P.; MCMILLAN, A. J. Translaminar fracture toughness testing of composites: A review. Polymer Testing, v.31, p. 481-489, 2012.

LAPENA, M.; MARINUCCI, G.; CARVALHO, O. Utilização da fibra de basalto em aplicações estruturais revisão e propostas de aplicação. In: 20을 Congresso Brasileiro de Engenharia e Ciência dos Materiais, 2012, Joinville. Anais do 20 Congresso Brasileiro de Engenharia e Ciência dos Materiais, 2012.

LEITÃO, E. da Silva. Caracterização mecânica de compósitos poliméricos bobinados em diversas orientações de reforço. Dissertação de mestrado, São Paulo, p. 79-80; 85, 2007.

MARINUCCI, G. Desenvolvimento, fabricação e análise de fratura de cilindros de fibra de carbono colapsados por pressão interna. Tese de doutorado, São Paulo, 2001.

MARINUCCI, G. Materiais compósitos poliméricos: fundamentos e tecnologia. Artliber Editora, São Paulo, 2011.

PACIORNIK, S; D'ALMEIDA, J. Digital microscopy and image analysis applied to composite materials characterization. Revista Matéria, v. 15, n. 2, p. 172$181,2010$.

PARNAS, R.; SHAW, M.; LIU, Q. Basalt Fiber Reinforced Polymer Composites. The New England Transportation Consortium, 2007.

PAVLOVSKI, D.; MISLAVSKY, B.; ANTONOV, A. CNG cylinder manufacturers test basalt fibre. Reinforced Plastics, abr. de 2007.

SINGHA, K. A Short Review on Basalt Fiber. International Journal of Textile Science, v.1(4), p.19-28, 2012.

SOUSA, J. R. M.; VIERO, P. F.; MAGLUTA, C.; ROITMAN, N. Experimental and Numerical Study on the Axial Compression Response of Flexible Pipes. Journal of Offshore Mechanics and Arctic Engineering. v. 134, Ago, 2012.

STRONG, Dr. A. B. Fundamentals of composites manufacturing: materials, methods and applications. Society of manufacturing engineers, USA, p. 5-6, 1989. 